\title{
Signaling through Dynamic Thresholds in Financial Covenants
}

\begin{abstract}
Among private loan contracts with covenants originated during 1996-2012, 35\% have financial covenant thresholds that automatically increase according to a predetermined schedule. Firms that accept these dynamic thresholds receive a lower interest spread and improve their creditworthiness relative to matched control firms. However, in the event of a covenant violation, these firms are less likely to receive a waiver, more likely to pay higher waiver fees, experience greater investment cuts, and are more likely to switch lead lenders than control firms. Overall, our findings suggest that signaling through dynamic thresholds in covenants is credible but costly to borrowers.
\end{abstract}

Keywords: loan covenant design, consequences of signaling, creditor control, information asymmetry

JEL Classification: G14, G21, G32, G34, M41 


\section{Introduction}

The literature on debt financing suggests that borrowers may be able to reduce the costs of asymmetric information by revealing their private information through contract terms. ${ }^{1}$ Financial covenants are a typical example of such contract terms, which contain information about borrowers' types. Since financial covenants serve as "tripwires" that limit agency problems and allocate control rights to creditors upon default, covenant thresholds negotiated between borrowers and lenders likely reflect firm's private information about its expected creditworthiness.

Covenants may have constant thresholds that remain at the same level throughout the duration of the loan, or they may have dynamic thresholds that automatically change to prespecified levels according to a predetermined schedule. For instance, the minimum allowed fixed charge coverage ratio for a borrower at loan initiation could be 1.65. A dynamic covenant threshold feature would automatically raise the covenant threshold to 1.75 after one year (as illustrated in Appendix A). Crucially, dynamic covenant thresholds are prevalent in loan contracts; $35 \%$ of the private loan contracts with covenants originated during 1996-2012 incorporate financial covenant thresholds that automatically increase according to a predetermined schedule.

Prior literature suggests that high-quality borrowers signal to differentiate themselves through their loan contract terms (e.g., Zimmerman 1975; Aghion and Bolton 1992; Dewatripont and Tirole 1994; Garleanu and Zwiebel 2009). But, there is relatively limited evidence for signaling using dynamic covenant thresholds or evidence that indicates whether this signaling is credible. In addition, a large literature documents that creditors exercise control rights after covenant violations and that creditors influence firms' investment, financing, and operating decisions (e.g., Chava and Roberts 2008; Nini, Sufi, and Smith 2008, 2012; Roberts and Sufi 2009; Ozelge and Saunders 2012; Saunders and Song 2014). Again, there is very limited evidence on how creditors' ex post decisions after covenant violations are related to

\footnotetext{
${ }^{1}$ For example, Stiglitz and Weiss 1981, 1983; Chan and Kanats 1985; Demiroglu and James 2010; Manso, Strulovici, and Tchistyi 2010.
} 
the ex ante information revealed at loan initiation. We address these gaps in the literature by investigating the economic consequences for borrowers that accept financial covenants with dynamic thresholds, both at the origination of the loan and-more importantly-if they fail to deliver the performance they signaled.

In general, borrowers have incentives to signal positive information to differentiate themselves from others. Signaling through financial covenant thresholds may increase the credibility of signaling, since violating covenants will transfer control rights to the creditors. However, this may not necessarily imply that all signaling through covenants is equally credible. Signaling through dynamic covenant thresholds may be subject to higher uncertainty, since the incentives underlying such signaling are likely to differ from the incentives underlying signaling through constant covenant thresholds. If a firm accepts financial covenants with constant thresholds, it implies that the firm has fewer risk-shifting opportunities (e.g., Demiroglu and James 2010) and is expected to maintain at least its current financial condition. In contrast, if a firm accepts financial covenants with dynamic thresholds, this implies that the firm will take on investment projects that could generate additional positive cash flows and improve its creditworthiness. Since expected future creditworthiness is based on managers' projections, managers may have incentives to inflate future prospects or to be overly optimistic if the expected costs of failure to deliver the expected performance are not high. For example, since renegotiations are common in private lending (Denis and Wang 2014; Roberts 2015), managers may rely on renegotiations with lenders to relax covenants after loan originations or to request a waiver for covenant violations (e.g., Chava, Wang, and Zou 2017). Alternatively, managers may expect lenders to delay terminating projects or delay liquidating assets after covenant violations, due to sunk costs and information asymmetry (i.e., dynamic adverse selection, see Bolton and Dewatripont 2005).

For signaling through financial covenants with dynamic thresholds to be effective in mitigating the problems associated with information asymmetry, we expect two important conditions to hold: (1) borrowers receive some benefits if they signal an improvement in future 
creditworthiness, and (2) the economic consequences of covenant violations are likely to be more severe than if they had not signaled. The first condition is necessary, since a borrower is unlikely to agree to covenants with increasing requirements if there are no benefits, holding everything else equal. The second condition is pertinent to prevent dynamic adverse selection and to maintain the credibility of the signal. If failure to improve the creditworthiness as signaled does not lead to severe consequences, opportunistic borrowers are likely to mimic others with good prospects and send a false signal about future prospects. ${ }^{2}$ In this paper, we document the incidence of signaling through dynamic covenant thresholds, and we document both the benefits of signaling at loan initiation and the ex post signaling costs when firms violate covenants.

We collect all the loan contracts for public firms in the Dealscan database from 1996 to 2012, and we supplement these data with the SEC filings data. For covenant violation data, we start with the sample from Roberts and Sufi (2009) and extend it to 2015 using a similar text search algorithm. The appendices provide details of the construction of the dynamic covenant thresholds and the text search algorithm. In addition, we retrieve the information on covenant violation waivers and waiver fees from these filings. When compared to firms that accept covenants with constant thresholds, we find that, on average, firms that accept dynamic thresholds have a higher default risk, lower profitability, and raise more funds from loans. Loans that include financial covenants with dynamic thresholds also have higher interest spreads and longer maturity.

The descriptive evidence indicates that firms that take loans with and without dynamic covenant thresholds are not directly comparable. Firms with high creditworthiness, or those with few investment opportunities, may find it unnecessary to signal or find it impossible to signal an improvement in creditworthiness. The net benefits of signaling through dynamic

\footnotetext{
${ }^{2}$ Notably, we do not suggest that creditors necessarily pre-commit to a harsher treatment of borrowers that have signaled. Covenant violations raise red flags about the credibility of information that managers revealed at loan initiation and the quality of the firm's projects. These more severe consequences could reflect that creditors quickly update their evaluation on firm risk and act conservatively on the information implied by covenant violations.
} 
covenant thresholds for these firms are likely to be limited or even negative. Therefore, we control for observable differences between firms with and without dynamic covenant thresholds using a propensity score matched sample and conduct all our empirical tests on this sample. ${ }^{3}$

In our initial tests, we examine the consequences of signaling using dynamic covenant thresholds at loan origination. We find that, compared to the matched control group of borrowers which accept constant covenant thresholds, borrowers who accept covenants with dynamic thresholds receive loan spreads that are approximately 16 basis points lower. Consistent with this evidence, the equity market reaction to the announcements of loans with dynamic covenant thresholds is more positive: the 5-day abnormal stock return is approximately $1.02 \%$ higher relative to that for the matched loans with constant covenant thresholds.

We next examine the ex post performance of firms that accept dynamic covenant thresholds in their loan contracts. Overall, firms that accept financial covenants with dynamic thresholds exhibit a reduction in credit risk within four, eight and twelve quarters after loan origination. However, firms accepting dynamic covenant thresholds are also more likely to violate loan covenants than their matched control group with constant covenant thresholds. This result suggests that (a) some of the firms that accept dynamic covenant thresholds may be overly optimistic about their future prospects, or (b) some of these firms may deliberately overstate their future prospects to receive the benefits of signaling with dynamic covenant thresholds at loan origination.

Control rights are transferred to lenders after technical covenant violations, and lenders may use the threat of accelerating the loan to extract concessions from the borrower and influence the borrower's investment and financial policies (e.g., Chava and Roberts 2008). At minimum, the bargaining power of the lender relative to the borrower increases after

\footnotetext{
${ }^{3}$ For firm-loan observations that include financial covenants with dynamic thresholds (the treatment group), we identify a matched group with similar firm and loan characteristics, but accepting only financial covenants with constant thresholds (the control group) using a propensity matching approach. After matching, firms accepting covenants with dynamic thresholds are not significantly different from those in the control group. Loans that include financial covenants with dynamic thresholds have more covenants than loans in the control group and are insignificant in other terms. The sample for our empirical tests only includes firm-loan observations with similar characteristics but differing in covenant features.
} 
technical covenant violations. To examine how signaling relates to consequences of covenant violations, we focus on lenders' decisions on granting a waiver, changes in firm investment around violations, and the impact on lending relations for future financing.

Granting a waiver implies that creditors are not likely to intervene significantly in borrowers' operating and investment decisions at the moment of violation. We find that, controlling for firm performance at the time of covenant violations, firms that accept financial covenants with dynamic thresholds are less likely to receive a waiver. The probability of receiving a waiver on covenant violation is 10.7 percentage points lower. Further, waiver fees are also part of the monetary costs of covenant violations and we manually collect this information from SEC filings. The average waiver fee for our sample is $\$ 731,278$, and the median fee is $\$ 150,000$. The average waiver fee as a fraction of the deal amount is 53 basis points, and the median fee is 20 basis points. We find that, conditional on receiving a waiver, borrowers violating financial covenants with dynamic thresholds are more likely to pay a waiver fee than the matched control firms, and the probability of paying a waiver fee is 4.7 percentage points higher (evaluated at the mean). The former, on average, also pays higher fees relative to the deal amount. The results on waiver fees suggest that renegotiation costs are higher for firms violating financial covenants with dynamic thresholds, even if they receive a waiver.

Creditor intervention over firm investment is also costly to borrowers. We compare the consequences of covenant violation on firm investment. Borrowers that accept financial covenants with dynamic thresholds also exhibit a greater investment cut after covenant violations, by 0.25 percentage points, on average, and by 0.49 percentage points if they do not receive a waiver, relative to matched control firms. This suggests that creditors may be particularly concerned about the quality of firm investment projects if creditworthiness has not improved as expected. Their monitoring incentives are stronger if they decide not to grant a waiver to the borrower.

Finally, we examine whether violating financial covenants with dynamic thresholds affects the lending relationship. For those taking new loans after covenant violations, firms that 
accept financial covenants with dynamic thresholds in the previous loan are more likely to switch lead lenders: the probability of switching lead lenders is 10.6 percentage points higher. On average, they face a greater increase in interest spreads by 28 basis points for the new loan taken after the covenant violation, compared to matched control firms. If firms accepting financial covenants with dynamic thresholds switch lenders, they face an additional increase of 62 basis points in interest spreads for the next new loan taken. Overall, the evidence suggests that borrowers with dynamic covenant thresholds find it more costly to maintain the existing lending relationship if they fail to deliver the performance they had signaled at loan origination.

The results on the consequences of violating covenants indicate significant costs of signaling with dynamic covenant thresholds. These results may also be interpreted to mean that the signaling costs of dynamic covenant thresholds include (a) the incremental waiver fees that violating firms with dynamic covenant thresholds pay, (b) the additional investment cut after the covenant violations (c) the incremental interest spread increases for the loans taken after the covenant violations, and, (d) the higher probability of losing the lending relationship after the covenant violations that is also costly for borrowers. ${ }^{4}$ These ex post costs trade off with the benefits of signaling with dynamic covenant thresholds at loan origination and may be sufficient to make the signal credible.

Our study is closely related to Demiroglu and James (2010), who study the information conveyed through the selection of tight financial covenants. However, in their paper, firms signal through tight covenants at loan origination, in contrast to signaling with dynamic covenant thresholds in our paper. Therefore, the type of firms in their sample and the incentives to signal that they consider are different from those in our paper. Demiroglu and James (2010) suggest that accepting initial covenant tightness implies that these firms have fewer risk-shifting investment opportunities. They report a decrease in investment spending after loan origination, and they experience a lower investment cut if they violate covenants. In

\footnotetext{
${ }^{4}$ We thank an anonymous referee for encouraging us to pursue this avenue.
} 
contrast, we find that firms accepting financial covenants with dynamic thresholds appear to have greater investment opportunities. These firms show an increase in investment following loan origination and are more likely to have a capital expenditure covenant that relaxes restrictions on investment over time. In addition, the initial covenant slack tends to be greater for earnings-based covenants with dynamic thresholds at loan initiation (Li et al. 2016). So, the differences in regard to the nature of firms and their incentives explain the differences in the consequences of covenant violations documented in our paper and those documented in Demiroglu and James (2010).

The focus of our study also differs from the few prior studies on the determinants of adjustments in covenant requirements. Dichev and Skinner (2002) briefly mention the changing covenant requirements in their study of covenant slack, but they do not further explore them. Beatty, Weber, and Yu (2008) investigate state-contingent adjustments for net worth covenants (i.e., the buildup feature). The buildup feature is fundamentally different from the dynamic covenant thresholds feature. The former reflects lenders' conservatism in monitoring by automatically increasing the covenant threshold for net worth when earnings are positive, while the latter reflects firms' private information at loan initiation. A contemporaneous paper by Li et al. (2016) studies earnings-based covenants with increasing thresholds and the trade-off between initial covenant slack and increasing covenant thresholds. They assume that lenders will have stronger control rights ex post, but they do not provide any evidence on actual creditors' impact on borrowers that fail to deliver the performance as signaled. We expand the scope of their study by incorporating other financial covenants, and we focus extensively on how dynamic covenant thresholds are related to the consequences of covenant violations. Our study also fills a void in the literature by (a) examining the credibility of signaling, (b) how the consequences of covenant violations are associated with signaling at loan initiation, and (c) how signaling affects lending relationships. ${ }^{5}$ Our results show that signaling through

\footnotetext{
${ }^{5}$ Signaling future creditworthiness through covenants is also different from signaling creditworthiness through performance pricing provisions, which will not shift control rights to creditors if the signal is not credible.
} 
dynamic covenant thresholds is credible but costly to borrowers, since creditors react more negatively if a borrower fails to deliver the expected performance.

An early study by Beneish and Press (1993) documents some preliminary evidence on waivers using a small and hand-collected sample. But, to our knowledge, we are the first to use a large sample to document empirical evidence on lenders' decisions on waivers of covenant violations and analyze the waiver fees charged by lenders. Decisions on waivers are one of the outcomes of creditor-borrower negotiations, and they play an important role in determining how creditor control affects firm behavior through contracting. It is largely unknown what factors are associated with lenders' decisions on granting a waiver and how covenant waivers are related to the impact on firm investment after covenant violations. We examine whether creditors' decisions regarding waivers are associated with the information revealed at loan initiation and investment cuts after covenant violations, controlling for waiver decisions.

The remainder of this paper is organized as follows. In Section 2, we describe the sample and present descriptive evidence. We present our empirical evidence in Section 3 and Section 4. Section 5 includes discussions on additional evidence and robustness checks. We conclude the paper in Section 6.

\section{Data, Sample Construction, and Descriptive Statistics}

We obtain data on loan contracts for public firms from the LPC Dealscan database. Since covenants are designed at the loan package level, and each package may have multiple loan facilities, we use the maximum value of each contract term (e.g., maturity, indicator variable for secured loan, interest spread) across all facilities within a package. ${ }^{6}$ The sample of loan contracts starts in 1996 because electronic SEC filings are available from 1996 onward, and the sample ends in 2012 because we require at least three years of financial data after loan origination to observe borrowers' post-financing performance.

We then retrieve the credit agreements for the loan packages in our sample from 10-K, 10-

\footnotetext{
${ }^{6}$ Our results are robust if we use loan terms corresponding to the loan facility that has the longest maturity.
} 
Q, and 8-K SEC filings, and we identify the amended loan contracts in the Dealscan database following Nikolaev (2016). For covenant violation data, we start with the SEC links for reported covenant violations provided on Michael Roberts' website and firm-quarter violation data provided by Amir Sufi. Since their data end in 2012, we extend the sample to 2015 using a text search algorithm similar to the one introduced in Roberts and Sufi (2009). We also collect information on covenant violation waivers from firms' SEC filings. The details of our text search algorithm are described in Appendix B. Our methodology for identifying covenant violations and waivers is similar to that of Roberts and Sufi (2009).

Following Drucker and Puri (2009), we keep only those loan contracts that have at least one covenant, and we ensure that the sample only includes contracts with complete loan information. In most loan agreements, covenant thresholds are contractually set to increase nominal requirements over time. We exclude agreements that include covenants with decreasing nominal requirements, since they are very rare and are primarily used for firms under special circumstances. We also exclude financial firms (SIC codes 6000-6999) from our sample. The financial data and equity market information are from the COMPUSTAT/CRSP database.

We keep observations that feature all the information available on the following firm and loan characteristics: distance to default, book assets, Tobin's Q, return on assets (ROA), leverage, capital expenditure (Capex), loan amount to tangible assets, loan maturity, number of covenants, and loan spreads. The final sample contains 8,729 loan packages for 3,328 unique firms for the 1996-2012 period. Out of these 8,729 loan packages, 3,007 include covenants with dynamic thresholds.

Panel A of Table 1 reports the types of financial covenants used in our sample contracts and shows how frequently these covenants have dynamic thresholds. There are 16 types of financial covenants. For each financial covenant, we report (a) the number of loan packages that include the covenant, (b) the number of loan packages that include the covenant with dynamic thresholds, and (c) the percentage of loan packages that include the covenant with 
dynamic thresholds. The dynamic thresholds are most commonly imposed on covenants that monitor borrowers' ability to generate cash for debt payments (e.g., covenants on EBITDA, Debt to EBITDA, Interest Coverage).

Panel B of Table 1 presents descriptive statistics on covenant thresholds for each individual covenant between covenants with dynamic thresholds and those with constant thresholds. As shown in Columns (1) and (2), for covenants that require borrowers to maintain the financial ratio above the minimum threshold (e.g., cash interest coverage or current ratio), the nominal initial thresholds for covenants with dynamic thresholds are consistently lower than those for the corresponding covenants with constant thresholds. For covenants that require borrowers to maintain the financial ratio below the maximum thresholds allowed (e.g., leverage ratio or Debt-to-EBITDA), the nominal initial thresholds for covenants with dynamic thresholds are consistently higher than those for the corresponding covenants with constant thresholds. These patterns are not likely to be driven by differences in the definitions of covenant variables because of the consistency in how the nominal thresholds for covenants with dynamic thresholds differ from the nominal thresholds for covenants with constant thresholds. These descriptive statistics show that firms that accept dynamic covenant thresholds are significantly different from those that accept constant covenant thresholds in terms of both firm and loan characteristics.

Columns (3) and (4) report the mean percentage increase and the median percentage increase, respectively, in the nominal requirements for covenants with dynamic thresholds. The percentage increase in nominal requirements is calculated as (final ratio-initial ratio)/initial ratio. For the covenants that require borrowers to maintain a financial ratio below the maximum threshold allowed, the more negative the percentage change, the greater the increase in nominal requirements, since the final thresholds of these covenants are lower than the initial thresholds. For simplicity, we multiply the percentage change by -1 in these cases, so that the increase in requirements is represented by a positive number. On average, all covenants with dynamic thresholds show a material increase in requirements that ranges from $12 \%$ to $262 \%$, 
depending on the type of financial covenant.

In untabulated results, we find that financial covenants with dynamic thresholds are often included for financing purposes that may significantly change borrowers' credit risk and/or increase agency conflicts between shareholders and creditors. Among loan packages with dynamic covenant thresholds, the top three financing purposes are recapitalization (72\%), exit takeovers (59\%), and leveraged buyouts (54\%).

\section{Signaling through Dynamic Covenant Thresholds}

In this section, we first empirically examine firm and loan characteristics associated with the presence of dynamic thresholds in financial covenants and then describe our matching method for identifying comparable control groups. Next, we analyze the impact of including dynamic covenant thresholds on the interest spreads of the loan and whether dynamic covenant thresholds relate to the loan announcement returns for these firms. Finally, we consider the ex post performance of firms with dynamic covenant thresholds.

A. Firm and Loan Characteristics Associated with the Presence of Dynamic Thresholds in Financial Covenants

In this subsection, we empirically examine the firm and loan characteristics associated with the presence of dynamic thresholds in financial covenants using the following model:

$$
\begin{aligned}
\operatorname{Trend}_{i t}= & \gamma_{0}+\gamma_{1} * \text { Distance to Default } \\
i, t-1 & +\gamma_{2} * \text { Capex }_{i, t-1}+\gamma_{3} * \text { Tobin's }_{i, t-1} \\
& +\gamma_{4} * \log (\text { Assets })_{i, t-1}+\gamma_{5} * \mathrm{ROA}_{i, t-1}+\gamma_{6} * \text { Leverage }_{i, t-1} \\
& +\gamma_{7} * \operatorname{Loan} / \mathrm{PPE}_{i, t-1}+\gamma_{8} * \operatorname{Spread}_{i, t}+\gamma_{9} * \log (\text { Maturity })_{i, t} \\
& +\gamma_{10} * \log (\text { Total Covenants })_{i, t}+\gamma_{11} * \operatorname{Secured}_{i, t}+\gamma_{12} * \text { Amend }_{i, t} \\
& +\eta_{\text {industry }}+\nu_{\text {year-quarter }}+\varepsilon_{i, t}
\end{aligned}
$$


where subscript $i$ denotes loan package $\mathrm{i}$, and subscript $t$ denotes year-quarter $t$. For the dependent variable, Trend, we construct four alternative measures to capture the use of dynamic threshold covenants in loan contracts. The first measure, Trend Dummy, is equal to 1 if a loan package includes at least one covenant with dynamic thresholds, and 0 otherwise. The second measure, Trend\%, is the percentage of financial covenants that have dynamic thresholds. The third measure, Trend Slope, is the maximum percentage increase in covenant requirements, which is taken over all financial covenants included in the loan package. The fourth measure, $\frac{\text { Trend Slope }}{\text { Maturity }}$, is equal to the calculated Trend Slope scaled by loan maturity.

The variables that capture firm risk and profitability are: Distance to Default, Capex, Tobin's Q, Log(Assets), ROA, Leverage, and Loan/PPEE. The loan characteristics included are Spread, Maturity, an indicator for secured loans (Secured), and the number of covenants (Total Covenants). In addition, we also include an indicator variable to control for whether the loan contracts are new credit agreements or amended ones (Amend). We also control for industry fixed-effects $\left(\eta_{\text {industry }}\right)$ using the Fama-French 48 industries classification and yearquarter fixed effects. Standard errors are clustered at the firm level. Appendix C provides a detailed description of the variables used in the model.

Panel $\mathrm{C}$ of Table 1 reports the results for the determinant models of dynamic covenant thresholds. The dependent variables are each of the measures for the presence of dynamic covenant thresholds, respectively. Since nonlinear models, such as Logit and Tobit models, suffer from the incidental parameter problem in the presence of fixed effects, we use the fractional response model (FRM) with correlated random effects when the dependent variables are Trend Dummy and Trend\% (Neyman and Scott 1984; Wooldridge 2011). The results of these four models consistently show that borrowers' credit risk at loan initiation is positively associated with the presence of financial covenants with dynamic thresholds. In addition, in terms of size, leverage, and profitability, firms that accept covenants with dynamic thresholds appear to be significantly different from those that accept covenants with constant thresholds. The loans taken for the former also tend to have larger amounts, longer maturity, and more 
covenants. These pieces of evidence suggest that these two subsamples may not be directly comparable.

\section{B. Matching}

Since the characteristics of borrowers who accept financial covenants with dynamic thresholds are very different from those who accept financial covenants with constant thresholds, the economic costs and benefits of signaling are likely to be different for these two sets of firms. Therefore, to identify comparable firms, we match loan packages with dynamic covenant thresholds (the treated group) to those with constant covenant thresholds (the control group) based on the propensity to include dynamic covenant thresholds in contracts. The propensity scores are estimated from Model (1), using Trend Dummy as the dependent variable. Specifically, for every treated loan package, we select, with replacement, a propensity-matched control loan package that was originated in the same calendar year and has a propensity score that is closest to the treated package. We can find matched loan packages for 2,723 of the 3,007 loan packages with dynamic covenant thresholds. We report a detailed description of the matching methodology in Appendix D.

Table 2 compares firm and loan characteristics between those accepting dynamic covenant thresholds and those accepting constant covenant thresholds. Firm characteristics are measured as of the fiscal quarter just before the loan origination date. The treated group and the matched control groups show similar firm characteristics: they show no significant differences in all risk and profitability measures except leverage. Firms that accept financial covenants with dynamic thresholds have lower leverage than the matched control firms that accept financial covenants with constant thresholds. The difference in the means is weakly significant at the $10 \%$ level. In terms of loan characteristics, the only variable that is significantly different between the two groups is the average number of financial covenants. Compared to statistics based on the original sample, the differences in firm and loan characteristics between firms accepting dynamic covenant thresholds and those accepting constant covenant 
thresholds are significantly reduced. Our subsequent empirical analyses are all based on the propensity-matched sample and not the original sample.

\section{Impact of Dynamic Covenant Thresholds at Loan Origination}

We focus on two direct benefits related to signaling: the cost of loans and the investors' perception of firm value. We first analyze whether there is any benefit to the loan spreads for the borrower as a result of agreeing to dynamic covenant thresholds. Then, we investigate whether loan announcement returns are in line with an expected improvement in the creditworthiness of the borrowers who signal by accepting dynamic covenant thresholds.

\section{C.1. Interest Spread}

If accepting financial covenants with dynamic thresholds differentiates borrowers with similar credit risk, borrowers may be able to negotiate for a lower interest spread by committing themselves to comply with increasing covenant requirements. Signaling an improvement in future performance is likely to lower perceived risk for the lender. Hence, compared with firms of similar observable characteristics that have accepted constant covenant requirements, firms accepting financial covenants with dynamic thresholds are likely to receive lower interest rates, holding everything else equal. Notably, including a performance pricing provision is not likely to have the same screening effect as including financial covenants with dynamic thresholds. This is because the former does not shift creditor control rights to creditors if borrowers fail to improve their performance as projected, but the latter does shift control rights if this occurs.

We estimate the following model for the propensity-matched sample of loan packages to examine whether loan packages that include financial covenants with dynamic thresholds are associated with lower interest rates (Spread), ceteris paribus.

$$
\begin{aligned}
\operatorname{Spread}_{i t}= & \gamma_{0}+\gamma_{1} * \text { Trend Dummy }_{i, t}+\gamma_{2} * \text { Firm Characteristics }_{i, t-1} \\
& +\gamma_{3} * \text { Loan Characteristics } \\
i, t & +\eta_{\text {industry }}+\nu_{\text {year-quarter }}+\varepsilon_{i, t} .
\end{aligned}
$$


Table 3 presents the results with several model specifications. We find a significantly negative association between interest spreads and Trend Dummy, consistent across all specifications. When we include all the control variables, interest spreads are 16 basis points lower, on average, for loan packages with dynamic covenant thresholds (the treated group) than for loan packages with constant covenant thresholds (the control group), as shown in Column (3). The signs of coefficients on other control variables are consistent with the evidence documented in the prior literature. Our results imply that signaling an improvement in future creditworthiness is associated with lower loan spreads for borrowers who accept dynamic covenant thresholds. This finding contributes to the literature on the role of covenants in loan pricing (e.g., Bradley and Roberts 2015; Goyal 2005).

\section{C.2. Stock market reactions to loan origination announcements}

When applying for loans, managers provide projections of future performance as well as the time-line for firms to meet these projections. If accepting financial covenants with dynamic thresholds signals a credible reduction in firms' future credit risk, equity market participants are likely to respond favorably, because a reduction in credit risk implies a reduction in the cost of capital. We investigate how the stock market reacts to announcements of loans that include financial covenants with dynamic covenant thresholds, relative to the propensitymatched control group.

The dependent variable of our short term event study is 5-day abnormal returns $(-2,+2)$ around deal activation date (CAR), where expected returns are estimated from the CAPM model. To control for the information content implied by multiple covenants, we include initial covenant strictness at the loan package level, as proposed by Murfin (2012). The results are reported in Table 4. Consistent with our prediction, the coefficient on Trend Dummy is significantly positive. When including financing purpose fixed effects, as shown in Column (2), the 5-day abnormal returns around loan announcements for firms taking loans with dynamic covenant thresholds are 1.019 percentage points higher than those for their 
matched counterparts. This evidence suggests that accepting financial covenants with dynamic thresholds conveys positive information to the equity market, after controlling for other firm and loan characteristics.

\section{Ex post performance of firms accepting dynamic covenant thresholds}

In this section, we examine firms' performance after loan origination. First, we evaluate the credibility of the signal by examining whether borrowers accepting financial covenants with dynamic thresholds, on average, exhibit a reduction in future credit risk. We estimate the following regression on the propensity matched sample:

$$
\begin{aligned}
\Delta \operatorname{DTD}_{i,(t+1, t+n)}= & \gamma_{0}+\gamma_{1} * \text { Trend } \text { Dummy }_{i, t}+\gamma_{2} * \text { Firm Characteristics }_{i, t-1} \\
& +\gamma_{3} * \text { Loan Characteristics }_{i, t}+\eta_{\text {industry }}+\nu_{\text {year-quarter }}+\varepsilon_{i, t},
\end{aligned}
$$

where the dependent variable $\triangle D T D$ represents the changes in credit risk, computed as distance to default measured at nth quarter after loan origination minus the distance to default measured at the 1st quarter after loan origination. The firm-level control variables are measured one quarter before loan origination. Table 5 reports the results when future credit risk is measured at the 4th, 8th, and 12th quarters, respectively, after loan origination. The coefficient of Trend Dummy is positive, and it becomes significant at the $1 \%$ level within eight quarters after loan origination. Our results suggest that firms accepting covenants with dynamic thresholds continue to improve their creditworthiness during the 12 quarters that follow loan origination.

Second, we compare the likelihood of covenant violations between firms that accept covenants with dynamic thresholds and the matched control sample. If borrowers who accept financial covenants with dynamic thresholds are conservative in providing estimates, they may not face a higher likelihood of covenant violations, since it will be easier to meet the required thresholds or to commit immaterial violations that do not cause significant consequences (e.g., narrowly missing the target). If they intentionally overstate future prospects, or if they are overly opti- 
mistic about their prospects, borrowers accepting financial covenants with dynamic thresholds should be more likely to violate covenants after loan origination relative to the borrowers accepting financial covenants with constant thresholds .

We link the reported covenant violation to the outstanding loan in the quarter in which covenant violation occurs. If two or more loan packages are outstanding at the time of covenant violation, we assume that the firm violated all outstanding loan packages. We make this assumption because many loan contracts include a cross-default clause that renders a borrower in default if the borrower defaults on another obligation. ${ }^{7}$ For our matched sample, about $29.54 \%$ of loan contracts have covenants violations. The percentage of observations that have covenant violations is in the same range as those reported in prior studies: $25 \%$ to $32 \%$ of loans in Chava and Roberts (2008) and 25\% of firms in Roberts and Sufi (2009).

We also check the disclosure of covenant violation in the SEC filings for more details. For firms that accept financial covenants with dynamic thresholds and also report covenant violations, $54 \%$ disclose which specific covenant was violated (the remaining $46 \%$ do not disclose these details). Among the violations with detailed disclosures, $89 \%$ involve financial covenants (e.g., Debt/EBITDA), and among these, $96 \%$ are violations of covenants with dynamic thresholds. Therefore, based on the $54 \%$ of the sample that we can observe, we expect that if a firm has covenants with dynamic covenant thresholds, the reported covenant violation is very likely to be a violation of that covenant. Since we do not know which covenants the firms violated without the disclosure, we assume that the violation pattern is similar for the rest of the sample firms that do not disclose this specific information.

We estimate the fractional response model (FRM) to estimate the likelihood of covenant

\footnotetext{
${ }^{7}$ In fact, only about $24 \%$ of firms in our sample have more than one package outstanding when they violate covenants.
} 
violation on the propensity-matched sample:

$$
\begin{aligned}
\text { Violation }_{i}= & \gamma_{0}+\gamma_{1} * \text { Trend Dummy } \\
i, t & +\gamma_{2} * \text { Firm Characteristics }_{i, t-1} \\
& +\gamma_{3} * \text { Loan Characteristics } \\
i, t & +\eta_{\text {industry }}+\nu_{\text {year-quarter }}+\varepsilon_{i, t},
\end{aligned}
$$

where Violation is a dummy that equals 1 if a firm violates the covenants in the loan package i, and 0 otherwise. Firm characteristics are measured at one quarter before loan origination. Table 6 reports the results. Our results show that firms accepting financial covenants with dynamic thresholds are more likely to violate covenants than matched control firms. As shown in Column (3), with all the control variables, the coefficient of Trend Dummy is 0.329, which implies a 5.61 percentage points increase in the likelihood of covenant violation if a borrower accepts financial covenants with dynamic thresholds. Combining the results reported in Table 5, we suggest that although firms, on average, continue to improve creditworthiness as signaled, borrowers who accept dynamic threshold covenants, on average, have a higher likelihood of failing to deliver expected performance than the borrowers in the matched control group. Even if the consequences of violating covenants were similar for the treated group and the control group, a higher likelihood of covenant violations implies higher expected costs of signaling through dynamic thresholds.

\section{Is there a cost to signaling through dynamic covenant thresholds?}

In this section, we analyze whether borrowers that signaled an improvement in their creditworthiness incur any costs if their subsequent performance falls short of the signal. Specifically, we consider the consequences of covenant violations and examine whether they are associated with signaling through dynamic covenant thresholds at loan initiation.

\section{A. Consequences of covenant violations}

For borrowers, covenant violations normally have a negative impact, such as restrictions on access to credit lines (e.g., Sufi 2009; Campello et al. 2011), unfavorable changes in 
terms (e.g., higher fees, collateral requirements, or borrowing limits. Chava and Roberts 2008, Acharya, Almeida, Ippolito and Perez-Orive 2014). We examine whether borrowers who signaled through dynamic covenant thresholds experience more severe consequences. In the absence of a cost, borrowers may have incentives to provide overly optimistic projections to negotiate favorable loan terms. Hence, we expect that it will be costly for borrowers to commit to improve but fail to meet this expectation.

We first compare the likelihood of receiving a waiver and paying fees on the condition that a waiver is granted, controlling for firms' concurrent performance at covenant violations. Decisions about waivers are one of the outcomes of creditor-borrower negotiations, and they play an important role in how creditor control affects firm behavior through contracting. Next, we examine the impact on firm investment and the lending relationship after a borrower violates covenants. Creditor intervention over firm investment is one of the major controls that creditors have over firms and is critical to managers' decisions about seeking debt financing.

\section{B. Waivers on covenant violations}

Covenant violations increase uncertainty about the credibility of borrowers' signals and the quality of investment projects revealed by management. Creditors are likely to revise their evaluation of borrowers' creditworthiness based on the updated information revealed by covenant violations and by their interactions with management during the renegotiation process. Hence, creditors are likely to react more negatively to covenant violations by borrowers who had signaled an improvement in creditworthiness relative to similar borrowers who accepted constant covenant thresholds.

One manifestation of more negative creditor reactions is the decreased likelihood of granting a waiver. Since a package may be violated multiple times, and because lenders may be stricter on firms that repeatedly violated covenants (e.g., Freudenberg, Imbierowicz, Saunders, and Steffen, 2015), we focus on the first covenant violation for each package. The dependent variable Waiver is a binary variable, which is equal to 1 if creditors grant a waiver for that 
covenant violation and 0 otherwise. The firm-level control variables are measured at one quarter before the covenant violation to control for firms' financial condition at the time of covenant violations. We use the fractional response model (FRM) to estimate the likelihood of receiving a waiver after covenant violations for the propensity-matched sample of loan packages. Panel A of Table 7 shows the likelihood of receiving a waiver after covenant violation. When we include all the control variables as shown in Column (3), we find that borrowers accepting loans that include financial covenants with dynamic thresholds face 10.7 percent points decrease in the likelihood of receiving a waiver. This suggests that lenders tend to have stronger monitoring incentives for this set of borrowers. This evidence complements the few recent studies which show that lenders are more likely to grant waivers after covenant violations when they do not have strong monitoring incentives (see Wang and Xia 2014; Chava, Wang, and Zou 2017).

\section{Waiver fees charged by lenders}

When a borrower receives a waiver for a covenant violation, it might need to pay a waiver fee to the lender. The data on waiver fees are not available in Dealscan or in other commercial loan databases. We read SEC filings to manually collect the data on the fees for firms that received a waiver for covenant violations. In many cases, lenders also amend the loan contract in the meanwhile even if they grant a waiver to the violating firm. Hence, the waiver fees we report include fees for granting a waiver and amending contracts. The average waiver fee for our sample is $\$ 731,278$, and the median fee is $\$ 150,000$. The average waiver fee as a fraction of the deal amount is 53 basis points, and the median fee is 20 basis points.

Panel B of Table 7 reports the results on waiver fees. In Column (1), the dependent variable Waiver Fee Dummy is equal to 1 if a borrower who received the waiver paid a fee for it, and 0 otherwise. In Column (2), the dependent variable, Waiver Fees\%, is equal to total fees paid, scaled by the deal amount. ${ }^{8}$ Our results shows that, conditional on receiving a waiver

\footnotetext{
${ }^{8}$ If a firm does not disclose whether it paid the waiver fee, we set the value to zero.
} 
after covenant violations, borrowers who had accepted covenants with dynamic thresholds (treated sample) are more likely to pay a waiver fee and tend to pay higher fees, relative to the control sample. Column (1) shows that borrowers who had accepted dynamic covenant thresholds face 4.7 percent points increase in the likelihood of paying a waiver fee after a covenant violation. Leverage and the total number of financial covenants included in the loan package also significantly increase a borrower's waiver fees. ${ }^{9}$ Overall, these results indicate that the costs of violating covenants with dynamic thresholds are higher, even if these firms received a waiver.

\section{Investment cut}

Prior studies show that covenant violations lead to a reduction in firm investment (e.g., Chava and Roberts 2008; Nini, Smith, and Sufi 2012). To examine whether the impact of covenant violations on investment is associated with the presence of dynamic covenant thresholds, we apply a difference-in-differences design to compare the changes in investment expenditure (Capex) before and after covenant violations. For firms that violate covenants in the propensity-matched sample, we extract financial information starting four quarters before the reported covenant violation to four quarters after covenant violation. Table 8 presents the results. The variables of interest are the Trend Dummy and the interaction term, Post* Trend Dummy, where Post is a time dummy, that indicates whether the firm year-quarter is within four quarters after a covenant violation. All control variables are measured at the concurrent year-quarter around covenant violations. The coefficient on Trend Dummy is insignificant under various model specifications, which suggests that the investment expenditure of firms that accept financial covenants with dynamic thresholds is not significantly different from that of the control group before covenant violations. The coefficient on Post*Trend Dummy is significantly negative, which is consistent with our expectation that firms accepting financial covenants with dynamic thresholds experience a greater investment cut after violating

\footnotetext{
${ }^{9}$ The result is robust to excluding firms who did not disclose whether they had paid the waiver fee.
} 
covenants, as shown in Columns (1) and (2). In addition, as shown in Column (2), receiving a waiver mitigates the investment cut for borrowers accepting financial covenants with dynamic thresholds, and this change is weakly significant at $10 \%$ level. However, the investment cut is still greater for the violations on treated packages, even if borrowers receive a waiver.

\section{E. Lending relationship and interest spread on new loans}

Next, we examine whether violating covenants has a negative impact on the lending relationship for borrowers who have signaled an improvement in creditworthiness. First, we investigate whether borrowers are likely to switch lead lenders for the next new loan taken after the first reported covenant violation. We define the dependent variable Switch Lender as 1 if the lead lender of the first loan taken after covenant violation is different from that of the loan that was violated. The firm-level control variables are measured as of one quarter before covenant violation, and these loan characteristics are derived from the loan packages for which covenants were violated. We use a fractional response model to estimate the likelihood of switching lead lenders. Table 9 reports the results.

Column (1) presents the results when we include all firms that violate covenants. If a firm does not take any new loans after covenant violation, we set Switch Lender to zero. Column (2) reports the results for the subsample of firms that take a new loan. The results of both regressions show that borrowers accepting financial covenants with dynamic thresholds are more likely to switch the lead lender for the next loan taken after a covenant violation than the control group. For borrowers accepting dynamic covenant thresholds, the probability of switching the lead lender is 3.9 percentage points higher for the sample used in Column (1) and 5.1 percentage points higher for the sample used in Column (2). This evidence suggests that violating covenants with dynamic thresholds could lead to an increase in the likelihood of ending the lending relationship.

Next, we focus on changes in the interest spread for the subsample of firms that take a new loan after violating covenants. We calculate the difference between the interest spread 
on the first new loan taken after the violation and the interest spread of the original loan $(\Delta$ Spread $)$. The firm-level control variables are measured as of the quarter before covenant violation and the loan characteristics are taken from the loan packages for which covenants are violated. Table 10 reports the results.

We show that borrowers accepting financial covenants with dynamic thresholds face a greater increase in the interest spread, on average, after covenant violations than matched control firms. As shown in Column (3), violating covenants with increasing thresholds will lead to an additional increase of 27.9 basis points in the interest spread for the new loan taken. Furthermore, if borrowers switch lead lenders, they will face an additional 62.2 basis points increase in the interest spread. These results, taken together with the results of Table 9, are consistent with our expectation that violating covenants with dynamic thresholds incur more severe economic consequences than violating covenants with constant thresholds.

\section{Discussion}

Our results show that the consequences of covenant violations are more severe for firms that signal an improvement in creditworthiness through dynamic thresholds in financial covenants. At the surface level, this result may seem to contradict the conclusions of Demiroglu and James (2010). This inconsistency arises primarily because of the difference in our sample of signaling firms and in their incentives to signal. Demiroglu and James (2010) show that firms accepting covenants with tight initial slack have few investment opportunities, so they are less likely to engage in risk-shifting. In contrast, firms that accept financial covenants with dynamic thresholds appear to be riskier and appear to have more investment opportunities. To further illustrate these differences, we conduct the following tests:

First, we examine the changes in investment ( $\Delta$ Capex) after loan origination, and we report the results in Table 11. Demiroglu and James (2010) show that firms that accept tight initial covenant slack show a decrease in investment after loan origination. However, our results show that firms that accept financial covenants with dynamic requirements exhibit a 
continuing increase in investment within eight quarters after loan origination.

Second, we find that firms accepting financial covenants with dynamic covenant thresholds are more likely to face investment restrictions. Creditors normally include negative covenants to mitigate moral hazard and prevent excessive risk taking (Chava, Kumar, and Warga 2010). Results are reported in Table 12. As shown in Column (1) of Table 12, firms accepting financial covenants with dynamic covenant thresholds are also more likely to face a capital expenditure covenant. This evidence suggests that creditors are concerned about the risk-shifting investment opportunities of these firms. Column (2) shows that firms accepting financial covenants with dynamic covenant thresholds are also more likely to face a time-varying capital expenditure covenant that relaxes limits on investment over time. This result suggests that these firms will be allowed to increase investment expenditures if they can improve creditworthiness as signaled. Column (3) shows that the similar results of time-varying capital expenditure covenant that relaxes limits on investment over time for the subsample of loan packages with capital expenditure restrictions.

Third, the firms in Demiroglu and James (2010)'s sample have lower initial covenant slack. Firms accepting financial covenants with dynamic thresholds tend to have higher initial covenant slack, as shown by Li et al. (2016). This evidence suggests that the firms in our sample are different from those in Demiroglu and James (2010). We further examine the association between the covenant trend and the overall restrictiveness of covenants at the package level. Following Murfin (2012), we evaluate the overall covenant restrictiveness at the loan package level based on the joint distribution of the multiple financial ratios stipulated in the covenants. Table 13 reports the regression results. We find that, for firms that accept increasing thresholds, loan covenants are initially more restrictive at the package level than for the matched firms, which accept constant covenant thresholds. In addition, we find that the overall covenant restrictiveness increases over time for firms that accept increasing thresholds. This means that temporarily relaxing the requirements of one covenant does not necessarily suggest that lenders relax overall covenant restrictiveness. 
Overall, the evidence suggests that firms with a relatively high default risk and with more investment opportunities signal an improvement in future creditworthiness by accepting covenants with dynamic thresholds. Lenders still tend to maintain control over borrowers' investments through capital expenditure covenants, and they agree to contractually relax investment restrictions if firms improve their creditworthiness as expected. A firm's failure to meet expectations raises red flags regarding the credibility of the information revealed at loan initiation and the quality of the investment projects. Therefore, the observed consequences of covenant violations in our paper are more severe and the opposite of those documented in Demiroglu and James (2010), because creditors have different incentives to manage risk when firms signal through financial covenants with dynamic thresholds.

In untabulated results, we also examine whether supply-side factors are associated with the use of dynamic thresholds in loan covenants. We consider two supply-side factors: (a) HighRep, which denotes lenders that have better reputations, as defined in Drucker and Puri (2009), and (b) Default Experience, which measures lenders' recent default experiences, as defined in Murfin (2012). We find limited evidence that these two factors explain dynamic thresholds. More importantly, our main results remain robust to controlling for supply-side factors.

\section{Conclusion}

We investigate the economic consequences of borrowers signaling through financial covenants with dynamic thresholds that are present in about $35 \%$ of loan packages with covenants. Borrowers can signal their type to differentiate themselves from other borrowers for debt financing, and accepting financial covenants with dynamic thresholds signals an improvement in future creditworthiness. However, such signals are largely based on managerial projections of the firm's performance. There is limited evidence on whether such signaling is credible and how borrowers and creditors renegotiate after covenant violations.

Our results indicate that firms that accept financial covenants with dynamic thresholds 
receive a lower interest spread and have more positive equity market reactions to loan announcements compared to the matched control group that has financial covenants with constant thresholds. Ex post, firms accepting dynamic thresholds continue to reduce their credit risk in the three years after loan origination. However, they are also more likely to violate covenants. After violating covenants, firms that accept financial covenants with dynamic thresholds are less likely to receive a waiver. They are also more likely to pay higher waiver fees if they do receive the waiver as well as cut investment more, relative to the matched group, which has similar firm and loan characteristics but only accepts covenants with constant thresholds. If they take out a new loan after violating financial covenants with dynamic thresholds, borrowers also tend to switch lead lenders and pay a higher interest rate for their subsequent loans. These results are consistent with our expectations that signaling an improvement in creditworthiness tends to lead to more severe consequences if firms fail to deliver the performance as signaled.

Our study extends prior studies on signaling in debt markets by examining the credibility of signaling and the interactions between creditors and borrowers if borrowers fail to deliver the performance as signaled. We focus on a unique type of signaling through financial covenants, which are associated with managers' projections on the performance of investment. We show that both the information revealed at loan initiation and the updated information observed when covenant violations occur is associated with creditors' decisions. To our knowledge, we are also the first to document large-sample empirical evidence regarding lenders' decisions on waivers of covenant violations and waiver fees. Waiver decisions are closely related to creditor control over borrowers, and they affect firms' incentives in both signaling through contracting and risk-taking behavior ex post. We contribute to the literature on contract design by investigating how contract terms are interrelated and how they can help mitigate the adverse selection that arises from asymmetric information and risk dynamics. Our evidence sheds additional lights on how banks utilize firm private information to differentiate borrowers and monitor firm performance over the life of a loan so they can make informed decisions. 


\section{References}

Acharya, V.V., Almeida, H., Ippolito, F. and Perez-Orive, A., 2014. Bank lines of credit as contingent liquidity: A study of covenant violations and their implications. Working papers.

Aghion, P., and Bolton, P., 1992. An Incomplete Contracts Approach to Financial Contracting. The Review of Economic Studies 59:473:494.

Beatty, A., Weber, J., and Yu, J., 2008. Conservatism and Debt. Journal of Accounting $\&$ Economics 45:154-174.

Beneish, M., and Press, E., 1993. Cost of Technical Violation of Accounting-based Debt Covenants. Accounting Review 68:233-257.

Bharath, S.T., and Shumway, T., 2008. Forecasting Default with the Merton Distance to Default Model. Review of Financial Studies 21:1339-1369.

Bolton, P., and Dewatripont, M., 2005. Contract Theory. The MIT Press. Cambridge, MA.

Bradely, M, Roberts, M.R., 2015 The Structure and Pricing of Debt Covenants, Quarterly Journal of Finance, 5: 1-37.

Campello, M., Giambona, E., Graham, J.R. and Harvey, C.R., 2011. Liquidity management and corporate investment during a financial crisis. Review of Financial Studies, 24(6), pp.1944-1979.

Chan, Y., and G. Kanatas. 1985. Asymmetric Valuations and the Role of Collateral in Loan Agreements. Journal of Finance 17:84-95.

Chava, S., and Roberts, M.R., 2008. How Does Financing Impact Investment? The Role of Debt Covenants. Journal of Finance 63:2085-2121.

Chava, S., Kumar, P., and Warga, A., 2010. Managerial Agency and Bond Covenants. Review of Financial Studies 23: 1120-1148.

Chava, S., R. Wang, H. Zou, 2017. Covenants, Creditors' Simultaneous Equity Holdings, and Firm Investment Policies. Forthcoming in Journal of Financial and Quantitative Analysis.

Demiroglu, C., and James, C.M., 2010. The Information Content of Bank Loan Covenants. Review of Financial Studies 23:3700-3737.

Denis, D., and Wang, J., 2014. Debt covenant renegotiations and creditor control rights, Journal of Financial Economics, 113(3): 348-367.

Dewatripont, M., and J. Tirole, 1994. A Theory of Debt and Equity: Diversity of Securities and Manager-Shareholder Congruence. Quarterly Journal of Economics, 109: 1027-54.

Dichev, I.D., and Skinner, D.J., 2002. Large-Sample Evidence on the Debt Covenant Hypothesis. Journal of Accounting Research, 40:1091-1123. 
Drucker, S., and Puri, M., 2009. On Loan Sales, Loan Contracting, and Lending Relationships. Review of Financial Studies, 22:2835-2872.

Freudenberg, F., B. Imbierowicz, A. Saunders, and S. Steffen, 2015. Covenant Violations and Dynamic Loan Contracting. Working Paper.

Gârleanu, N., and Zwiebel, J., 2009. Design and Renegotiation of Debt Covenants. Review of Financial Studies, 22:749-81.

Goyal, Vidhan K., 2005. Market discipline of bank risk: Evidence from subordinated debt contracts. Journal of Financial Intermediation, 14: 318-350.

Kornai, J. (1979). "Resource-Constrained Versus Demand-Constrained Systems," Econometrica $47,801-819$.

Kornai, J. (1980). Economics of Shortage. Amsterdam: North Holland.

Li, N., Vasvari, F., and Moerman, R., 2016. Dynamic Threshold Values in Earnings-Based Covenants. Journal of Accounting and Economics, 61: 605-629.

Manso, Gustavo, Bruno Strulovici, and Alexei Tchistyi, 2010, Performance-sensitive debt. Review of Financial Studies, 23, 1819-1854.

Murfin, J., 2012. The Supply-Side Determinants of Loan Contract Strictness. Journal of Finance, 67:1565-1601.

Neyman, J., Scott, E.L., 1948. Consistent Estimation from Partially Consistent Observations. Econometrica, 16:1-32.

Nikolaev, V., 2016. Scope for Renegotiation in Private Debt Contracts. Working Paper, Chicago Booth School of Business.

Nini, G., Smith, D., and Sufi, A., 2009. Creditor Control Rights and Firm Investment Policy. Journal of Financial Economics, 92:400-420.

Nini, G., Smith, D., and Sufi, A., 2012. Creditor Control Rights, Corporate Governance, and Firm Value. Review of Financial Studies, 25:1713-1761.

Ozelge, S. and Saunders, A., 2012. The role of lending banks in forced CEO turnovers. Journal of Money, Credit and Banking, 44(4), 631-659.

Roberts, M.R., and A. Sufi, 2009. Control Rights and Capital Structure: An Empirical Investigation, Journal of Finance, 64, 1657-1695.

Roberts, M.R., 2015. The role of dynamic renegotiation and asymmetric information in financial contracting. Journal of Financial Economics, 116(1), 61-81.

Saunders, A. and Song, K, 2014. Bank Monitoring and CEO Risk-Taking Incentives. Available at SSRN: https://ssrn.com/abstract $=2509906$ or http://dx.doi.org/10.2139/ssrn.2509906 
Stiglitz, J.E., and Weiss, A., 1981. Credit Rationing in Markets with Imperfect Information. American Economic Review, 71:393-410.

Stiglitz, J.E., and Weiss A., 1983. Alternate Approaches to the Analysis of Markets with Asymmetric Information. American Economic Review 73:246-249.

Sufi, A., 2009. Bank lines of credit in corporate finance: An empirical analysis. Review of Financial Studies, 22(3), pp.1057-1088.

Wang, Y., H. Xia, 2014. Do Lenders Still Monitor When They Can Securitize Loans? Review of Financial Studies 27, 2354-2391.

Wooldridge, J., 2011. Fractional Response Models with Endogenous Explanatory Variables and Heterogeneity.

http://www.stata.com/meeting/chicago11/materials/chi11_wooldridge.pdf.

Zimmerman, C. 1975. An Approach to Writing Loan Agreement Covenants. Journal of Commercial Bank Lending, 58:2-17. 


\section{Appendices}

Appendix A: An Example of a Financial Covenant with Dynamic Covenant Thresholds

The following excerpt is from the loan contract signed on March 15, 1996 for Rite Aid Corp to finance a merger:

\begin{tabular}{ll} 
Administrative Agent & Morgan Guaranty Trust (6.0\%) \\
Managing Agents (4.8\%) & Bank of America \\
& Chase Manhattan Bank \\
& Citibank \\
& Mellon Bank \\
& NationsBank \\
& PNC Bank \\
& ABN AMRO Bank N.V. \\
& Bank of Nova Scotia \\
Co-agents (3.6\%) & Commerzbank AG \\
& Fuji Bank Ltd. \\
& Wachovia Bank \\
& $\$ 2,500,000,000$ \\
Term (Mos.) & $2 / 15 / 01$ \\
Maturity & 59 \\
\hline
\end{tabular}

Financial Covenants

Fixed Charge Coverage

FQE Minimum (x:1)

thru $11 / 97$

thru $11 / 98$

thru $11 / 00$

Ratio $=$ Consolidated EBIT + consolidated rent to consolidated interest charges + consolidated rent. Restructuring and similar charges related to the merger will not be used in the ratio calculation, provided the aggregate pre-tax amount of such charges is $<=\$ 163$ million. 


\section{Appendix B: Text Search Algorithm}

We start with the data on covenant violation available at Michael Roberts' website (see Roberts and Sufi, 2009). The original data ends at 2012 Q1. We extend the sample period of the data by collecting covenant violation information directly from 10-K, 10-Q, and 8-K SEC filings from 2012 Q2 to 2015 Q4. We modify the methodology employed Roberts and Sufi (2009) to automate collection of information related to covenant violations and to reduce false positive.

To improve the accuracy of our text search, we tested our algorithm using randomly selected quarters (i.e., the training sample) numerous times and revised the key words and search restrictions until we obtained an out-of-sample Type 1 and the Type 2 error rates of less than 5\%. For our final algorithm, the Type 1 error rate is $2 \%$, and Type 2 error rate is $3.55 \%$. We further test this algorithm using the sample available at Michael Roberts' website. Our algorithm successfully locates $96.45 \%$ of violations for the $10-\mathrm{Ks}, 8-\mathrm{Ks}$, and 10-Qs reported in his sample before any manual corrections.

Our final algorithm includes two steps. In the first step, the algorithm searches for the following keywords related to covenants, such as "covenant ratio", "interest coverage", "fixed charge", "loan to value", "leverage", "debt to equity", "debt to tangible net worth", "debt to net worth", "debt coverage", "debt service", "debt to ebitda", "ebitda requirement". If the algorithm can locate any of these keywords, it continues to search for the following terms within the same sentence of the initial hit: "violated", "breached", "defaulted", "failed to comply", "resulting in default", "resulting in a default", "resulting in event of default", "resulting in an event of default", "was in breach", "was in noncompliance", "was in non-compliance", "was not in compliance", "was in default", "was in technical default", "was in violation", "were in breach", "were in noncompliance", "were in non-compliance", "were not in compliance", "were in default", "were in technical default", "were in violation", "are in breach", "are in noncompliance", "are in non-compliance", "are not in compliance", "are in default", "are in technical default", "are in violation", "is in breach", "is in noncompliance", "is in non-compliance", "is 
not in compliance", "is in default", "is in technical default", "is in violation", "resulted in a breach", "resulted in noncompliance", "resulted in non-compliance", "resulted in default", "resulted in technical default", "resulted in a technical fault", "resulted in violation", "resulting in breach", "resulting in noncompliance", "resulting in non-compliance", "resulting in default", "resulting in technical default", "resulting in violation", "represents a breach", "represents a noncompliance", "represents a non-compliance", "represents a default", "represents a technical default", "represents a violation". In addition, we also search for the terms "in compliance" and "complied" followed by the word "except" in the same sentence of the initial hit. In the second step, we search again through all the matches identified in the first step and eliminate those hits in which any of the following texts appears in the same sentence: "allege", "alleged", "allegation", "lawsuit", "legal", "implied covenant", "defendant", "plaintiff", would", "will", "can", "could", "if", "may", "might", "shall", "should", "customary", "future", "inability", "in past", "in the past", "time to time", "no", "none", "not", "nothing" and the words "viol", "breach", "default", "compl".

We use a similar methodology to obtain data on covenant waivers. The algorithm searches for the text "waiv" within three lines before and after the line in which covenant violation information is disclosed. Next, we eliminate those matches in which any of the following texts appears in the same sentence as "waiv": "not", receiv", "unable to", "being sought", "cannot assure", "no assurance", "failure to" "discussion", "if", "may", "might", "seeking", "no", "none", "not", "nothing".

To form the final sample for our covenant violation tests, we merge the following: (a) the violation data from Amir Sufi's website,(b) Michael Robert's data, and (c) our extended dataset from 2012 to 2015 . 
Appendix C: Variable Definitions

Distance to Default: The number of standard deviations from the default threshold, estimated using the KMV Merton model as in Bharath and Shumway (2008).

Capex: $\quad$ Capital expenditures scaled by the book value of assets.

Tobin's Q: $\quad$ Market value of assets scaled by the replacement value of firm assets.

Assets: The total value of a firm's book assets (in millions of USD).

ROA: $\quad$ Income before extraordinary items, divided by total assets.

Leverage: $\quad$ The total amount of debt divided by total assets.

Loan/PPEE: $\quad$ The total amount of the loan granted, scaled by net property, plant, and equipment.

Spread: $\quad$ Interest spread on the package, in basis points.

Maturity: $\quad$ The maximum number of months to loan maturity granted under the package.

Total Covenants: Total number of covenants.

Secured: $\quad$ A binary variable equal to 1 if the loan is collateralized and 0 otherwise.

Amend: $\quad$ A binary variable equal to 1 if the loan is an amended loan.

Strictness: $\quad$ Covenant restrictiveness at loan package level, as proposed by Murfin (2012). 


\section{Appendix D: Propensity Matching}

We start with 8,729 loan packages (3,007 loan packages with dynamic covenant thresholds and 5,722 packages with constant thresholds) by 3,328 unique firms in the merged CRSP/Compustat \& Dealscan database for the period 1996 to 2012, with nonmissing values of size, Tobin's Q, ROA, leverage, investments, distance to default, loan to tangible assets, loan maturity, number of covenants, and loan spread. We estimate the propensity to include financial covenants with dynamic thresholds in credit agreement, using the model described in Equation (1). We omit observations that are not on common support. For every signal loan package with dynamic covenant thresholds (treatment group), we search for a propensitymatched package that was originated in the same calendar year and does not include covenants with dynamic covenant thresholds (control group). That is, for every treated package, we select (with replacement) a control package that was originated in the same calendar year and is closest to the treated package in terms of the propensity to include financial covenants with dynamic thresholds. Following this procedure, we are able to match 2,723 treated loan packages to 2,723 control loan packages. Before matching, firms taking loans that included financial covenants with dynamic thresholds are significantly different from those taking loans that include financial covenants with constant thresholds in terms of firm and loan characteristics. After the matching, the sample of treated packages shows similar characteristics as the matched control group, as shown in Table 2. 
Table 1: Panel A: Dynamic Thresholds in Financial Covenants

This table reports the number of loan packages that include each type of financial covenant, the number of loan packages that include the specific financial covenant with dynamic thresholds, and the percentage of loan packages that include the specific financial covenant with dynamic thresholds.

\begin{tabular}{lrrr}
\hline \hline Types of & $\begin{array}{r}\text { No. of Pkgs. } \\
\text { with the } \\
\text { Covenant }\end{array}$ & $\begin{array}{r}\text { No.of Pkgs. } \\
\text { with Dynamic } \\
\text { Covenant } \\
\text { Thresholds }\end{array}$ & $\begin{array}{r}\text { \% of Pkgs. } \\
\text { with Dynamic } \\
\text { Covenant } \\
\text { Thresholds }\end{array}$ \\
\hline Min. EBITDA & 736 & 432 & $58.70 \%$ \\
Max. Senior Debt to EBITDA & 818 & 415 & $50.73 \%$ \\
Max. Debt to EBITDA & 4830 & 2014 & $41.70 \%$ \\
Min. Cash Interest Coverage & 92 & 29 & $31.52 \%$ \\
Min. Interest Coverage & 3252 & 870 & $26.75 \%$ \\
Min. Fixed Charge Coverage & 3100 & 821 & $26.48 \%$ \\
Max. Loan to Value & 8 & 2 & $25.00 \%$ \\
Min. Quick Ratio & 188 & 38 & $20.21 \%$ \\
Max. Senior Leverage & 11 & 2 & $18.18 \%$ \\
Max. Debt to Tangible Net Worth & 650 & 116 & $17.85 \%$ \\
Min. Debt Service Coverage & 508 & 85 & $16.73 \%$ \\
Max. Debt to Equity & 48 & 8 & $16.67 \%$ \\
Max. Leverage ratio & 1583 & 176 & $11.12 \%$ \\
Min. Current Ratio & 827 & 51 & $6.17 \%$ \\
Net Worth & 1527 & 0 & $0.00 \%$ \\
Tangible Net Worth & 1359 & 0 & $0.00 \%$ \\
\hline \hline
\end{tabular}




\section{Table 1: Panel B: Nominal Initial Thresholds and Changes in Covenant Requirements}

This table presents initial threshold levels for covenants with dynamic thresholds and for the sample with constant thresholds. The table also reports the percentage increases in covenant requirements over the life of the loan contracts for covenants with dynamic thresholds. For the Min EBITDA covenant, we scale the dollar amount requirements by firms' total assets of the year before entering the loan contract. The percentage increase in covenant requirement is calculated as, (final ratio-initial ratio)/initial ratio. For Max (Senior) Debt-to-EBITDA and leverage related covenants, we multiply the percentage change by -1 since the final covenant thresholds are lower than the initial ones.

\begin{tabular}{lrrrr}
\hline \hline Financial Covenant Type & Initial Thresholds & $\begin{array}{c}\text { \% Increase in Requirement } \\
\text { for the Covenant with } \\
\text { Dynamic Thresholds } \\
\text { Mean }\end{array}$ & $\begin{array}{c}\text { Median } \\
\text { (n) }\end{array}$ \\
& $(1)$ & $(2)$ & $(3)$ & $(4)$ \\
\hline Max. Debt to EBITDA & 4.33 & 3.40 & $24 \%$ & $21 \%$ \\
Max. Debt to Equity & 2.55 & 1.94 & $19 \%$ & $19 \%$ \\
Max. Debt to Tangible Net Worth & 3.06 & 1.77 & $25 \%$ & $20 \%$ \\
Max. Leverage ratio & 0.68 & 0.58 & $14 \%$ & $11 \%$ \\
Max. Loan to Value & 2.23 & 2.00 & $12 \%$ & $12 \%$ \\
Max. Senior Debt to EBITDA & 3.47 & 2.71 & $29 \%$ & $25 \%$ \\
Max. Senior Leverage & 0.75 & 0.45 & $17 \%$ & $17 \%$ \\
Min. Cash Interest Coverage & 1.42 & 2.17 & $54 \%$ & $32 \%$ \\
Min. Current Ratio & 1.12 & 1.33 & $23 \%$ & $20 \%$ \\
Min. Debt Service Coverage & 1.33 & 1.44 & $32 \%$ & $17 \%$ \\
Min. EBITDA & 0.07 & 0.10 & $262 \%$ & $60 \%$ \\
Min. Fixed Charge Coverage & 1.29 & 1.46 & $46 \%$ & $19 \%$ \\
Min. Interest Coverage & 2.27 & 2.75 & $42 \%$ & $30 \%$ \\
Min. Quick Ratio & 0.91 & 1.05 & $41 \%$ & $23 \%$ \\
\hline \hline
\end{tabular}


Table 1: Panel C: Determinants of the Presence of Dynamic Covenant Thresholds

This table reports the tests on the determinants of dynamic covenant thresholds in loan packages. FRM stands for the fractional response model with logit link function, and OLS stands for the linear regression model. Trend Dummy is equal to 1 if the loan package includes at least one covenant with dynamic thresholds, and 0 otherwise. Trend\% is percentage of covenants with dynamic thresholds. Trend Slope, is the maximum percentage increase in covenant requirements from its initial thresholds to the final thresholds, where the maximum is taken over all financial covenants of the loan package. Firm characteristics are measured as of the quarter before loan origination. Distance to Default is estimated using the KMV Merton model (Bharath and Shumway, 2008). Capex is capital expenditures scaled by the book value of assets. Tobin's $Q$ is the market value of assets scaled by the replacement value of firm assets. Book Assets is the book value of total assets in millions of USD. ROA is income before extraordinary items, divided by the total assets. Leverage is the total amount of debt, divided by the total assets. Loan/PPEE is the total amount of the loan granted under the package in millions scaled by net property, plant, and equipment. Spread is the interest spread on the package in basis points. Maturity is the maximum number of months before loan maturity granted under the package. Total Covenants is the total number of covenants. Secured equals 1 if the loan is collateralized, and 0 otherwise. Amend equals 1 if the package is an amended loan. The robust standard errors clustered by firms are reported in parentheses. $* * * p<0.01, * * p<0.05, * p<0.1$.

\begin{tabular}{|c|c|c|c|c|}
\hline & $\begin{array}{c}\text { (1) } \\
\text { Trend Dummy }\end{array}$ & $\begin{array}{c}(2) \\
\text { Trend\% }\end{array}$ & $\begin{array}{c}(3) \\
\text { Trend Slope }\end{array}$ & $\begin{array}{c}(4) \\
\text { Trend Slope/ } \\
\text { Maturity }\end{array}$ \\
\hline & FRM & FRM & OLS & OLS \\
\hline Distance to Default & $\begin{array}{c}-0.054^{* * *} \\
(0.010)\end{array}$ & $\begin{array}{c}-0.049^{* * *} \\
(0.008)\end{array}$ & $\begin{array}{c}-1.361^{* * *} \\
(0.490)\end{array}$ & $\begin{array}{c}-0.057^{* * *} \\
(0.021)\end{array}$ \\
\hline Capex & $\begin{array}{l}-2.478 \\
(1.690)\end{array}$ & $\begin{array}{c}-2.042 \\
(1.256)\end{array}$ & $\begin{array}{c}50.871 \\
(52.626)\end{array}$ & $\begin{array}{c}0.992 \\
(1.880)\end{array}$ \\
\hline Tobin's Q & $\begin{array}{l}-0.005 \\
(0.034)\end{array}$ & $\begin{array}{l}-0.039 \\
(0.026)\end{array}$ & $\begin{array}{l}2.390^{*} \\
(1.295)\end{array}$ & $\begin{array}{c}0.060 \\
(0.054)\end{array}$ \\
\hline Log(Assets) & $\begin{array}{c}0.094^{* * *} \\
(0.028)\end{array}$ & $\begin{array}{c}0.043^{* *} \\
(0.019)\end{array}$ & $\begin{array}{c}1.803^{* *} \\
(0.751)\end{array}$ & $\begin{array}{c}0.078^{* *} \\
(0.032)\end{array}$ \\
\hline ROA & $\begin{array}{c}-2.168^{* *} \\
(1.041)\end{array}$ & $\begin{array}{l}-0.242 \\
(0.617)\end{array}$ & $\begin{array}{c}-99.496^{* *} \\
(47.373)\end{array}$ & $\begin{array}{l}-2.736 \\
(1.813)\end{array}$ \\
\hline Leverage & $\begin{array}{c}0.709^{* * *} \\
(0.204)\end{array}$ & $\begin{array}{c}0.545^{* * *} \\
(0.126)\end{array}$ & $\begin{array}{c}-23.951^{* *} \\
(12.142)\end{array}$ & $\begin{array}{c}-1.127^{* *} \\
(0.532)\end{array}$ \\
\hline Loan/PP\&E & $\begin{array}{c}0.016^{* * *} \\
(0.006)\end{array}$ & $\begin{array}{c}0.008^{* * *} \\
(0.003)\end{array}$ & $\begin{array}{c}0.235 \\
(0.227)\end{array}$ & $\begin{array}{c}0.005 \\
(0.008)\end{array}$ \\
\hline Spread & $\begin{array}{c}0.317^{* * *} \\
(0.038)\end{array}$ & $\begin{array}{c}0.163^{* * *} \\
(0.020)\end{array}$ & $\begin{array}{c}10.722^{* * *} \\
(1.209)\end{array}$ & $\begin{array}{c}0.361^{* * *} \\
(0.056)\end{array}$ \\
\hline Log (Maturity) & $\begin{array}{c}0.492^{* * *} \\
(0.060)\end{array}$ & $\begin{array}{c}0.274^{* * *} \\
(0.047)\end{array}$ & $\begin{array}{l}(1.282) \\
(1.947)\end{array}$ & $\begin{array}{c}-0.744^{* * *} \\
(0.152)\end{array}$ \\
\hline Secured & $\begin{array}{l}-0.134 \\
(0.085)\end{array}$ & $\begin{array}{l}-0.107 \\
(0.066)\end{array}$ & $\begin{array}{c}2.507 \\
(1.812)\end{array}$ & $\begin{array}{c}0.131 \\
(0.083)\end{array}$ \\
\hline Log (Total Covenants) & $\begin{array}{c}1.877^{* * * *} \\
(0.079)\end{array}$ & $\begin{array}{c}0.347^{* * *} \\
(0.062)\end{array}$ & $\begin{array}{c}12.961^{* * * *} \\
(2.952)\end{array}$ & $\begin{array}{c}0.385^{* * *} \\
(0.130)\end{array}$ \\
\hline Amend & $\begin{array}{c}0.048 \\
(0.067)\end{array}$ & $\begin{array}{c}0.006 \\
(0.053)\end{array}$ & $\begin{array}{l}-1.657 \\
(3.148)\end{array}$ & $\begin{array}{l}-0.039 \\
(0.140)\end{array}$ \\
\hline Observations & 8,729 & 8,729 & 8,729 & 8,729 \\
\hline R-squared & 0.295 & 0.071 & 0.059 & 0.046 \\
\hline Industry \& Year-Qtr FE & Yes & Yes & Yes & Yes \\
\hline
\end{tabular}


Table 2: Descriptive Statistics: Firm and Loan Characteristics for the Propensity-Matched Sample

This table reports the statistics on firm and loan characteristics for the treatment sample and the propensity-matched sample, respectively. Distance to default is estimated using the KMV Merton model (Bharath and Shumway, 2008). Capex is capital expenditures scaled by the book value of assets. Tobin's $Q$ is the market value of assets scaled by the replacement value of firm assets. Book Assets is the book value of total assets in millions of USD. ROA is income before extraordinary items, divided by total assets. Leverage is the total amount of debt, divided by the total assets. Loan/PPEE is the total amount of the loan granted under the package in millions scaled by net property, plant, and equipment. Spread is the interest spread on the package in basis points. Maturity is the maximum number of months to loan maturity granted under the package. Total Covenants is the total number of covenants. Secured equals 1 if the loan is collateralized, and 0 otherwise. Amend equals 1 if the package is an amended loan. The table also reports whether the differences in means by t-test are statistically significant. $* * * p<0.01, * * p<0.05, * p<0.1$.

\begin{tabular}{lrrrrrr}
\hline \hline & \multicolumn{3}{c}{ Constant Thresholds } & \multicolumn{3}{c}{ Dynamic Thresholds } \\
\hline & $(1)$ & $(2)$ & $(3)$ & $(4)$ & $(5)$ & $(6)$ \\
& Mean & Std. Dev. & Median & Mean & Std. Dev. & Median \\
Distance to Default & 4.776 & 4.007 & 4.255 & 5.076 & 4.153 & 4.322 \\
Capex & 0.017 & 0.020 & 0.011 & 0.017 & 0.021 & 0.010 \\
Tobin's Q & 1.328 & 0.821 & 1.100 & 1.378 & 0.894 & 1.103 \\
Assets & 2007.735 & 4650.006 & 513.190 & 1930.590 & 4363.676 & 483.778 \\
ROA & 0.003 & 0.031 & 0.008 & 0.006 & 0.028 & 0.008 \\
Leverage & 0.341 & 0.218 & 0.332 & 0.320 & 0.207 & $0.311^{*}$ \\
Loan/PP\&E & 3.535 & 8.152 & 1.202 & 3.843 & 8.013 & 1.375 \\
Spread & 249.932 & 170.588 & 212.500 & 234.215 & 130.114 & 225.000 \\
Maturity & 49.842 & 22.640 & 50.000 & 51.058 & 20.936 & 59.000 \\
Total Covenants & 6.305 & 2.424 & 6.000 & 6.683 & 2.742 & $7.000^{* * *}$ \\
Secured & 0.752 & 0.432 & 1.000 & 0.738 & 0.440 & 1.000 \\
Amend & 0.739 & 0.439 & 1.000 & 0.738 & 0.440 & 1.000 \\
\hline \hline
\end{tabular}


Table 3: Dynamic Covenant Thresholds and Loan Spreads for the Propensity-Matched Sample

This table reports the effect of the presence of increasing covenant thresholds on loan spreads using the propensity-matched sample. The dependent variable Spread is the initial interest spread in basis points. Trend Dummy equals 1 if the loan package includes one or more covenants with dynamic thresholds, and 0 otherwise. Distance to Default is estimated using the KMV Merton model (Bharath and Shumway, 2008). Capex is capital expenditures scaled by the book value of assets. Tobin's $Q$ is the market value of assets scaled by the replacement value of firm assets. Book Assets is the book value of total assets in millions of USD. ROA is income before extraordinary items, divided by the total assets. Leverage is the total amount of debt, divided by the total assets. Loan/PPEE is the total amount of the loan granted under the package in millions scaled by net property, plant, and equipment. Financial variables are measured as of the quarter before loan origination. Maturity is the maximum number of months before loan maturity granted under the package. Total Covenants is the total number of covenants. Secured equals 1 if the loan is collateralized, and 0 otherwise. Amend equals 1 if the package is an amended loan. The robust standard errors clustered by firms are reported in parentheses. $* * * p<0.01, * * p<0.05, * p<0.1$.

\begin{tabular}{lccc}
\hline \hline & $(1)$ & $(2)$ & $(3)$ \\
& Spread & Spread & Spread \\
\hline Trend Dummy & $-15.522^{* *}$ & $-15.961^{* *}$ & $-15.980^{* *}$ \\
& $(7.557)$ & $(6.703)$ & $(6.694)$ \\
Distance to Default & & $-9.133^{* * *}$ & $-9.244^{* * *}$ \\
& & $(1.156)$ & $(1.143)$ \\
Capex & & 56.441 & 60.368 \\
& & $(137.089)$ & $(138.156)$ \\
Tobin's Q & & -3.079 & -3.048 \\
& & $(3.162)$ & $(3.132)$ \\
Log (Assets) & & $-6.791^{* * *}$ & $-6.865^{* * *}$ \\
& & $(2.311)$ & $(2.307)$ \\
ROA & & $-323.467^{* * *}$ & $-321.802^{* * *}$ \\
& & $(112.702)$ & $(111.971)$ \\
Leverage & & -17.812 & -18.001 \\
& & $(19.182)$ & $(19.194)$ \\
Loan/PP\&E & & $1.535^{* * *}$ & $1.538^{* * *}$ \\
& & $(0.498)$ & $(0.487)$ \\
Log (Maturity) & & $-15.433^{* *}$ & $-15.105^{* *}$ \\
& & $(6.015)$ & $(6.013)$ \\
Log (Total Covenants) & & $48.575^{* * *}$ & $49.409^{* * *}$ \\
& & $(6.790)$ & $(6.730)$ \\
Secured & & $77.658^{* * *}$ & $77.657^{* * *}$ \\
& & $(6.497)$ & $(6.531)$ \\
Amend & & & $-14.181^{* *}$ \\
& & & $(6.849)$ \\
Observations & & & \\
R-squared & & & 5,446 \\
Industry \& Year-Qtr FE & Yes & & Yes \\
\hline \hline
\end{tabular}




\section{Table 4: Loan Announcement Returns for the Propensity-Matched Sample}

This table examines loan announcement effects. CAR [-2,2] denotes 5-day CAR (\%) around the deal active date. Trend Dummy is equal to 1 if the loan package includes at least one covenant with dynamic thresholds, and 0 otherwise. Distance to Default is estimated using the KMV Merton model (Bharath and Shumway, 2008). Capex is capital expenditures scaled by the book value of assets. Tobin's $Q$ is the market value of assets scaled by the replacement value of firm assets. Book Assets is the book value of total assets in millions of USD. ROA is income before extraordinary items, divided by the total assets. Leverage is the total amount of debt, divided by the total assets. Loan/PPEE is the total amount of the loan granted under the package in millions scaled by net property, plant, and equipment. Spread is the interest spread on the package in basis points. Maturity is the maximum number of months before loan maturity granted under the package. Total Covenants is the total number of covenants. Secured equals 1 if the loan is collateralized, and 0 otherwise. Amend equals 1 if the package is an amended loan. Strictness is overall covenant restrictiveness, estimated at the package level following Murfin (2012). The robust standard errors clustered by firms are reported in parentheses. $* * * p<0.01, * * p<0.05, * p<0.1$.

\begin{tabular}{|c|c|c|}
\hline & $\begin{array}{c}(1) \\
\text { CAR }[-2,+2]\end{array}$ & $\begin{array}{c}(2) \\
\text { CAR }[-2,+2]\end{array}$ \\
\hline Trend Dummy & $\begin{array}{c}0.944^{* *} \\
(0.366)\end{array}$ & $\begin{array}{c}1.019^{* * *} \\
(0.367)\end{array}$ \\
\hline Distance to Default & $\begin{array}{c}-0.138^{* *} \\
(0.065)\end{array}$ & $\begin{array}{c}-0.125^{*} \\
(0.067)\end{array}$ \\
\hline Capex & $\begin{array}{l}-13.077 \\
(12.400)\end{array}$ & $\begin{array}{l}-13.386 \\
(12.573)\end{array}$ \\
\hline Tobin's Q & $\begin{array}{c}-0.427^{*} \\
(0.239)\end{array}$ & $\begin{array}{c}-0.425^{*} \\
(0.243)\end{array}$ \\
\hline Log (Assets) & $\begin{array}{c}0.067 \\
(0.192)\end{array}$ & $\begin{array}{c}0.112 \\
(0.196)\end{array}$ \\
\hline $\mathrm{ROA}$ & $\begin{array}{c}7.861 \\
(9.407)\end{array}$ & $\begin{array}{c}7.143 \\
(9.289)\end{array}$ \\
\hline Leverage & $\begin{array}{c}0.121 \\
(1.174)\end{array}$ & $\begin{array}{c}0.167 \\
(1.187)\end{array}$ \\
\hline Loan/PP\&E & $\begin{array}{l}0.106^{* *} \\
(0.042)\end{array}$ & $\begin{array}{c}0.103^{* *} \\
(0.043)\end{array}$ \\
\hline Secured & $\begin{array}{l}-0.360 \\
(0.471)\end{array}$ & $\begin{array}{l}-0.372 \\
(0.473)\end{array}$ \\
\hline Log (Maturity) & $\begin{array}{c}0.170 \\
(0.376)\end{array}$ & $\begin{array}{c}0.069 \\
(0.387)\end{array}$ \\
\hline Log (Total Covenants) & $\begin{array}{l}-0.358 \\
(0.444)\end{array}$ & $\begin{array}{l}-0.359 \\
(0.460)\end{array}$ \\
\hline Amend & $\begin{array}{l}0.718^{*} \\
(0.410)\end{array}$ & $\begin{array}{l}0.774^{*} \\
(0.416)\end{array}$ \\
\hline Spread & $\begin{array}{l}-0.444 \\
(0.291)\end{array}$ & $\begin{array}{l}-0.406 \\
(0.297)\end{array}$ \\
\hline Strictness & $\begin{array}{l}-0.003 \\
(0.012)\end{array}$ & $\begin{array}{l}-0.001 \\
(0.012)\end{array}$ \\
\hline Observations & 1,690 & 1,690 \\
\hline R-squared & 0.127 & 0.136 \\
\hline Industry \& Year-Qtr FE & Yes & Yes \\
\hline Deal Purpose FE & No & Yes \\
\hline
\end{tabular}


Table 5: Change in Risk after Loan Origination for the Propensity-Matched Sample

This table compares the changes in creditworthiness after loan origination for packages with dynamic thresholds with the changes in creditworthiness for the propensity-matched packages with constant thresholds. The dependent variable, $\Delta D T D(1, t)$, is computed as the distance to default measured $t$ quarters after loan origination minus the distance to default measured at the quarter after loan origination. Trend Dummy equals 1 if the loan package includes one or more covenants with dynamic thresholds, and 0 otherwise. Distance to Default is estimated using the KMV Merton model (Bharath and Shumway, 2008). Capex is capital expenditures scaled by the book value of assets. Tobin's $Q$ is the market value of assets scaled by the replacement value of firm assets. Book Assets is the book value of total assets in millions of USD. $R O A$ is income before extraordinary items, divided by the total assets. Leverage is the total amount of debt, divided by the total assets. Loan/PPEE is the total amount of the loan granted under the package in millions scaled by net property, plant, and equipment. Financial variables are measured as of the quarter before loan origination. Spread is the interest spread on the package in basis points. Maturity is the maximum number of months before loan maturity granted under the package. Total Covenants is the total number of covenants. Secured equals 1 if the loan is collateralized, and 0 otherwise. Amend equals 1 if the package is an amended loan. The robust standard errors clustered by firms are reported in parentheses. $* * * p<0.01, * * p<0.05, * p<0.1$.

\begin{tabular}{lccc}
\hline \hline & $(1)$ & $(2)$ & $(3)$ \\
& $\Delta$ DTD $[+1,+4]$ & $\Delta$ DTD $[1,+8]$ & $\Delta$ DTD $[+1,+12]$ \\
\hline Trend Dummy & $0.214^{*}$ & $0.467^{* * *}$ & $0.528^{* * *}$ \\
Capex & $(0.118)$ & $(0.169)$ & $(0.194)$ \\
& -4.020 & -2.504 & -0.736 \\
Tobin's Q & $(3.195)$ & $(4.726)$ & $(5.517)$ \\
& -0.055 & -0.188 & 0.044 \\
Log (Assets) & $(0.081)$ & $(0.116)$ & $(0.136)$ \\
& 0.035 & 0.029 & $0.186^{* * *}$ \\
ROA & $(0.043)$ & $(0.055)$ & $(0.068)$ \\
& 1.124 & 4.243 & -4.154 \\
Leverage & $(1.969)$ & $(2.628)$ & $(3.587)$ \\
& 0.516 & 0.217 & -0.340 \\
Loan/PP\&E & $(0.426)$ & $(0.487)$ & $(0.590)$ \\
Secured & $-0.017^{* *}$ & -0.012 & -0.025 \\
& $(0.007)$ & $(0.011)$ & $(0.017)$ \\
Log (Maturity) & 0.132 & -0.114 & 0.011 \\
& $(0.156)$ & $(0.234)$ & $(0.245)$ \\
Log (Total Covenants) & -0.171 & $-0.470^{* * *}$ & $-0.475^{* *}$ \\
& $(0.124)$ & $(0.174)$ & $(0.192)$ \\
Spread & -0.078 & 0.034 & 0.152 \\
& $(0.135)$ & $(0.198)$ & $(0.217)$ \\
Amend & 0.017 & 0.139 & $0.321^{* *}$ \\
Observations & $(0.102)$ & $(0.115)$ & $(0.130)$ \\
R-squared & 0.007 & -0.097 & 0.204 \\
Industry \& Year-Qtr FE & $(0.135)$ & $(0.195)$ & $(0.230)$ \\
\hline \hline
\end{tabular}




\section{Table 6: Likelihood of Covenant Violation for the Propensity-Matched Sample}

This table reports the tests on the likelihood of covenant violations using the fractional regression model on the propensity-matched sample of loan packages. The dependent variable Violation equals 1 if a firm is in violation of a covenant while the package is outstanding. Trend Dummy equals 1 if the loan package includes one or more covenants with dynamic thresholds, and 0 otherwise. Distance to Default is estimated using the KMV Merton model (Bharath and Shumway, 2008). Capex is capital expenditures scaled by the book value of assets. Tobin's $Q$ is the market value of assets scaled by the replacement value of firm assets. Book Assets is the book value of total assets in millions of USD. $R O A$ is income before extraordinary items, divided by the total assets. Leverage is the total amount of debt, divided by the total assets. Loan/PPEEE is the total amount of the loan granted under the package in millions scaled by net property, plant, and equipment. Financial variables are measured as of the quarter before loan origination. Spread is the interest spread on the package in basis points. Maturity is the maximum number of months before loan maturity granted under the package. Total Covenants is the total number of covenants. Secured equals 1 if the loan is collateralized, and 0 otherwise. Amend equals 1 if the package is an amended loan. The robust standard errors clustered by firms are reported in parentheses. $* * * p<0.01, * * p<0.05, * p<0.1$.

\begin{tabular}{lccc}
\hline \hline & $(1)$ & $(2)$ & $(3)$ \\
& Violation & Violation & Violation \\
\hline Trend Dummy & $0.292^{* * *}$ & $0.324^{* * *}$ & $0.329^{* * *}$ \\
& $(0.101)$ & $(0.103)$ & $(0.103)$ \\
Distance to Default & & $-0.095^{* * *}$ & $-0.091^{* * *}$ \\
& & $(0.017)$ & $(0.017)$ \\
Capex & & $7.110^{* * *}$ & $7.087^{* * *}$ \\
& & $(2.716)$ & $(2.701)$ \\
Tobin's Q & & -0.017 & -0.022 \\
& & $(0.069)$ & $(0.068)$ \\
Log (Assets) & & $-0.358^{* * *}$ & $-0.364^{* * *}$ \\
& & $(0.046)$ & $(0.046)$ \\
ROA & & 0.744 & 0.683 \\
& & $(1.999)$ & $(2.024)$ \\
Leverage & & -0.352 & -0.339 \\
& & $(0.359)$ & $(0.367)$ \\
Loan/PP\&E & & -0.009 & -0.010 \\
Secured & & $(0.007)$ & $(0.007)$ \\
Log (Maturity) & & $0.271^{* *}$ & $0.265^{*}$ \\
& & $(0.138)$ & $(0.140)$ \\
Log (Total Covenants) & & $0.575^{* * *}$ & $0.569^{* * *}$ \\
& & $(0.106)$ & $(0.107)$ \\
Spread & & -0.065 & -0.102 \\
& & $(0.118)$ & $(0.119)$ \\
Amend & & $0.210^{* * *}$ & $0.217^{* * *}$ \\
& & $(0.048)$ & $(0.047)$ \\
Observations & & $0.494^{* * *}$ \\
Pseudo R-squared & & & $(0.116)$ \\
Industry \& Year-Qtr FE & Yes & Yes & Yes \\
\hline \hline
\end{tabular}


Table 7: Panel A: Likelihood of Receiving Waiver after First Covenant Violation for the Propensity-Matched Sample

This table reports the results on the likelihood of a waiver conditional on covenant violation using the fractional response model. The dependent variable Waiver equals 1 if creditors grant a waiver for that covenant violation, and 0 otherwise. We control for financial performance measured at the quarter before covenant violation. Trend Dummy equals 1 if the loan package includes one or more covenants with dynamic thresholds, and 0 otherwise. Distance to Default is estimated using the KMV Merton model (Bharath and Shumway, 2008). Capex is capital expenditures scaled by the book value of assets. Tobin's $Q$ is the market value of assets scaled by the replacement value of firm assets. Book Assets is the book value of total assets in millions of USD. ROA is income before extraordinary items, divided by the total assets. Leverage is the total amount of debt, divided by the total assets. Loan/PPEE is the total amount of the loan granted under the package in millions scaled by net property, plant, and equipment. Financial variables are measured at the quarter before reported covenant violation. Spread is the interest spread on the package in basis points. Maturity is the maximum number of months before loan maturity granted under the package. Total Covenants is the total number of covenants. Secured equals 1 if the loan is collateralized, and 0 otherwise. Amend equals 1 if the package is an amended loan. The robust standard errors clustered by firms are reported in parentheses. $* * * p<0.01, * * p<0.05, * p<0.1$.

\begin{tabular}{lccc}
\hline \hline & $(1)$ & $(2)$ & $(3)$ \\
Model: FRM & Waiver & Waiver & Waiver \\
\hline Trend Dummy & $-0.351^{* *}$ & $-0.438^{* * *}$ & $-0.432^{* * *}$ \\
Distance to Default & $(0.156)$ & $(0.169)$ & $(0.170)$ \\
& & 0.010 & 0.009 \\
Capex & & $(0.030)$ & $(0.030)$ \\
& & 4.775 & 5.368 \\
Tobin's Q & $(6.127)$ & $(6.179)$ \\
& & 0.016 & 0.036 \\
Log (Assets) & & $(0.179)$ & $(0.187)$ \\
& & $-0.187^{* *}$ & $-0.201^{* *}$ \\
ROA & & $(0.078)$ & $(0.079)$ \\
& & -3.589 & -3.811 \\
Leverage & & $(2.444)$ & $(2.424)$ \\
& & $-1.526^{* * *}$ & $-1.515^{* * *}$ \\
Loan/PP\&E & & $(0.398)$ & $(0.403)$ \\
& & 0.005 & 0.004 \\
Secured & & $(0.025)$ & $(0.025)$ \\
& & 0.154 & 0.132 \\
Log (Maturity) & & $(0.257)$ & $(0.259)$ \\
Log (Total Covenants) & & 0.020 & 0.016 \\
& & $(0.193)$ & $(0.192)$ \\
Spread & & 0.275 & 0.235 \\
& & $(0.203)$ & $(0.203)$ \\
Amend & $-0.161^{* *}$ & $-0.179^{* *}$ \\
& & $(0.071)$ & $(0.071)$ \\
Observations & & $0.506^{* * *}$ \\
Industry FE & & & $(0.191)$ \\
Pseudo R-squared & 0.091 & 0.130 & 0.136 \\
\hline \hline
\end{tabular}


Table 7: Panel B: Likelihood of Paying Waiver Fees after the First Violation for the PropensityMatched Sample

This table reports the results of the determinants of waiver fees conditional on a firm receiving a waiver. The dependent variable Waiver Fee Dummy is equal to 1 if a firm pays waiver fees, and 0 otherwise. The dependent variable Waiver Fees\% is equal to the total amount of fees paid scaled by the deal amount. Our sample consists of first covenant violations on the propensity-matched sample of loan packages. We control for financial information before covenant violation. Trend Dummy equals 1 if the loan package includes one or more covenants with dynamic thresholds, and 0 otherwise. Distance to Default is estimated using the KMV Merton model (Bharath and Shumway, 2008). Capex is capital expenditures scaled by the book value of assets. Tobin's $Q$ is the market value of assets scaled by the replacement value of firm assets. Book Assets is the book value of total assets in millions of USD. ROA is income before extraordinary items, divided by the total assets. Leverage is the total amount of debt, divided by the total assets. Loan/PPEEE is the total amount of the loan granted under the package in millions scaled by net property, plant, and equipment. Financial variables are measured at the quarter before the reported covenant violation. Spread is the interest spread on the package in basis points. Maturity is the maximum number of months before loan maturity granted under the package. Total Covenants is the total number of covenants. Secured equals 1 if the loan is collateralized, and 0 otherwise. Amend equals 1 if the package is an amended loan. The robust standard errors are reported in parentheses. $* * * p<0.01, * * p<0.05, * p<0.1$.

\begin{tabular}{|c|c|c|}
\hline Model: FRM & $\begin{array}{c}\text { (1) } \\
\text { Waiver Fee Dummy }\end{array}$ & $\begin{array}{c}(2) \\
\text { Waiver Fees\% }\end{array}$ \\
\hline Trend Dummy & $\begin{array}{l}0.473^{*} \\
(0.252)\end{array}$ & $\begin{array}{c}0.969^{* * *} \\
(0.361)\end{array}$ \\
\hline Distance to Default & $\begin{array}{c}-0.098^{*} \\
(0.051)\end{array}$ & $\begin{array}{l}-0.010 \\
(0.084)\end{array}$ \\
\hline Capex & $\begin{array}{c}9.289 \\
(10.773)\end{array}$ & $\begin{array}{c}14.598 \\
(13.977)\end{array}$ \\
\hline Tobin's Q & $\begin{array}{c}0.073 \\
(0.334)\end{array}$ & $\begin{array}{c}0.063 \\
(0.579)\end{array}$ \\
\hline Log(Book Assets) & $\begin{array}{c}0.036 \\
(0.121)\end{array}$ & $\begin{array}{l}-0.102 \\
(0.144)\end{array}$ \\
\hline $\mathrm{ROA}$ & $\begin{array}{c}7.315 \\
(4.930)\end{array}$ & $\begin{array}{c}10.123 \\
(10.430)\end{array}$ \\
\hline Leverage & $\begin{array}{c}1.945^{* *} \\
(0.818)\end{array}$ & $\begin{array}{c}3.717^{* * *} \\
(1.242)\end{array}$ \\
\hline Loan/PP\&E & $\begin{array}{c}0.112^{* * *} \\
(0.037)\end{array}$ & $\begin{array}{l}-0.089 \\
(0.065)\end{array}$ \\
\hline Secured & $\begin{array}{l}-0.340 \\
(0.409)\end{array}$ & $\begin{array}{l}-0.481 \\
(0.419)\end{array}$ \\
\hline Log (Maturity) & $\begin{array}{c}-0.588^{* *} \\
(0.295)\end{array}$ & $\begin{array}{c}0.188 \\
(0.331)\end{array}$ \\
\hline Log (Total Covenants) & $\begin{array}{c}1.109^{* * *} \\
(0.380)\end{array}$ & $\begin{array}{c}0.970^{* *} \\
(0.445)\end{array}$ \\
\hline Amend & $\begin{array}{c}0.237 \\
(0.335)\end{array}$ & $\begin{array}{c}-0.737^{* *} \\
(0.344)\end{array}$ \\
\hline Spread & $\begin{array}{c}-0.438^{* * *} \\
(0.137)\end{array}$ & $\begin{array}{l}-0.044 \\
(0.140)\end{array}$ \\
\hline Observations & 537 & 537 \\
\hline Industry FE & Yes & Yes \\
\hline Pseudo R-squared & 0.280 & 0.146 \\
\hline
\end{tabular}


Table 8: Investment Cuts after First Covenant Violation for the Propensity-Matched Sample

This table reports the results on changes in investment before and after a covenant violation for propensity-matched loan packages using a difference-in-differences design. We restrict the package year-quarter observations to be within four quarters around the first covenant violation. The dependent variable, Capex, is the capital expenditures scaled by the book value of assets. Trend Dummy is equal to 1 if the loan package includes one or more covenants with dynamic thresholds, and 0 otherwise. Post is equal to 1 if the package year quarter observation is on or within 4 quarters after a covenant violation, and 0 otherwise. Waiver is 1 if creditors grant a waiver for that covenant violation, and 0 otherwise. Distance to Default is estimated using the KMV Merton model (Bharath and Shumway, 2008). Tobin's $Q$ is the market value of assets scaled by the replacement value of firm assets. Book Assets is the book value of total assets in millions of USD. ROA is income before extraordinary items, divided by the total assets. Leverage is the total amount of debt, divided by the total assets. Loan/PPEE is the total amount of the loan granted under the package in millions scaled by net property, plant, and equipment. Total Covenants is the total number of covenants. Secured equals 1 if the loan is collateralized, and 0 otherwise. The robust standard errors clustered by firms are reported in parentheses. $* * * p<0.01, * * p<0.05, * p<0.1$.

\begin{tabular}{|c|c|c|}
\hline & $\begin{array}{c}(1) \\
\text { Capex }\end{array}$ & $\begin{array}{c}(2) \\
\text { Capex }\end{array}$ \\
\hline Trend Dummy & $\begin{array}{c}0.153 \\
(0.188)\end{array}$ & $\begin{array}{c}0.245 \\
(0.190)\end{array}$ \\
\hline Post x Trend Dummy & $\begin{array}{c}-0.576^{* * *} \\
(0.141)\end{array}$ & $\begin{array}{c}-0.486^{* * *} \\
(0.140)\end{array}$ \\
\hline Waiver $\mathrm{x}$ Post & $\begin{array}{r}-0.293^{*} \\
(0.166)\end{array}$ & $\begin{array}{c}-0.206 \\
(0.160)\end{array}$ \\
\hline Trend Dummy x Waiver x Post & $\begin{array}{r}0.477^{* *} \\
(0.212)\end{array}$ & $\begin{array}{l}0.372^{*} \\
(0.203)\end{array}$ \\
\hline Distance to Default & & $\begin{array}{c}0.029 \\
(0.019)\end{array}$ \\
\hline Tobin's Q & & $\begin{array}{l}0.282^{*} \\
(0.169)\end{array}$ \\
\hline Log (Assets) & & $\begin{array}{l}-0.042 \\
(0.047)\end{array}$ \\
\hline $\mathrm{ROA}$ & & $\begin{array}{c}2.005 \\
(1.565)\end{array}$ \\
\hline Leverage & & $\begin{array}{c}0.408 \\
(0.335)\end{array}$ \\
\hline Loan/PP\&E & & $\begin{array}{c}-0.073^{* * *} \\
(0.014)\end{array}$ \\
\hline Secured & & $\begin{array}{c}0.048 \\
(0.135)\end{array}$ \\
\hline Log (Total Covenants) & & $\begin{array}{c}-0.375^{* *} \\
(0.157)\end{array}$ \\
\hline Observations & 5,464 & 5,464 \\
\hline R-squared & 0.318 & 0.341 \\
\hline Industry \& Year-Qtr FE & Yes & Yes \\
\hline
\end{tabular}


Table 9: Lending Relationship after First Covenant Violation for the Propensity-Matched Sample

This table reports the results of the likelihood of switching lenders following covenant violations for the propensity-matched sample. The sample used in Column (1) includes borrowers that either take or do not take new loans following a covenant violation. The sample used in Column (2) includes only borrowers who take new loans. Switch lender is a dummy that equals 1 if the borrower switches to a different lead lender for the first loan taken after a covenant violation. If a firm does not take any new loans after a covenant violation, we set Switch Lender to 0. Trend Dummy equals 1 if the loan package includes one or more covenants with dynamic thresholds, and 0 otherwise. Distance to Default is estimated using the KMV Merton model (Bharath and Shumway, 2008). Capex is capital expenditures scaled by the book value of assets. Tobin's $Q$ is the market value of assets scaled by the replacement value of firm assets. Book Assets is the book value of total assets in millions of USD. ROA is income before extraordinary items, divided by the total assets. Leverage is the total amount of debt, divided by the total assets. Loan/PPEE is the total amount of the loan granted under the package in millions scaled by net property, plant, and equipment. Financial variables are measured at the quarter before reported covenant violation. Spread is the interest spread on the package in basis points. Maturity is the maximum number of months before loan maturity granted under the package. Total Covenants is the total number of covenants. Secured equals 1 if the loan is collateralized, and 0 otherwise. Amend equals 1 if the package is an amended loan. The robust standard errors clustered by firms are reported in parentheses. $* * * p<0.01, * * p<0.05, * p<0.1$.

\begin{tabular}{|c|c|c|}
\hline & $\begin{array}{c}\text { (1) } \\
\text { Switch Lender }\end{array}$ & $\begin{array}{c}(2) \\
\text { Switch Lender }\end{array}$ \\
\hline Trend dummy & $\begin{array}{c}0.394^{* * *} \\
(0.119)\end{array}$ & $\begin{array}{c}0.511^{* * *} \\
(0.173)\end{array}$ \\
\hline Distance to Default & $\begin{array}{c}-0.075^{* * *} \\
(0.025)\end{array}$ & $\begin{array}{c}-0.132^{* * *} \\
(0.036)\end{array}$ \\
\hline Tobin's Q & $\begin{array}{c}0.378^{* * * *} \\
(0.138)\end{array}$ & $\begin{array}{c}0.047 \\
(0.191)\end{array}$ \\
\hline Log (Assets) & $\begin{array}{c}0.217^{* * *} \\
(0.049)\end{array}$ & $\begin{array}{c}-0.132^{*} \\
(0.075)\end{array}$ \\
\hline $\mathrm{ROA}$ & $\begin{array}{c}1.792 \\
(1.665)\end{array}$ & $\begin{array}{l}-2.338 \\
(2.612)\end{array}$ \\
\hline Leverage & $\begin{array}{c}-0.988^{* * *} \\
(0.339)\end{array}$ & $\begin{array}{c}-0.521 \\
(0.431)\end{array}$ \\
\hline Capex & $\begin{array}{c}3.990 \\
(3.971)\end{array}$ & $\begin{array}{c}10.522^{*} \\
(5.924)\end{array}$ \\
\hline Loan/PP\&E & $\begin{array}{c}-0.023 \\
(0.022)\end{array}$ & $\begin{array}{c}0.014 \\
(0.031)\end{array}$ \\
\hline Spread & $\begin{array}{c}-0.177^{* * *} \\
(0.044)\end{array}$ & $\begin{array}{c}-0.202^{* * *} \\
(0.050)\end{array}$ \\
\hline Secured & $\begin{array}{c}-0.280 \\
(0.181)\end{array}$ & $\begin{array}{c}0.196 \\
(0.236)\end{array}$ \\
\hline Log (Maturity) & $\begin{array}{l}-0.025 \\
(0.141)\end{array}$ & $\begin{array}{l}0.345^{*} \\
(0.193)\end{array}$ \\
\hline Log (Total Covenants) & $\begin{array}{c}0.611^{* * *} \\
(0.157)\end{array}$ & $\begin{array}{c}0.150 \\
(0.230)\end{array}$ \\
\hline Amend & $\begin{array}{l}-0.121 \\
(0.148)\end{array}$ & $\begin{array}{c}-0.413^{*} \\
(0.213)\end{array}$ \\
\hline Observations & 1,446 & 930 \\
\hline Pseudo R-squared & 0.088 & 0.155 \\
\hline Industry FE & Yes & Yes \\
\hline
\end{tabular}


Table 10: Interest Spread of the New Loan Taken after First Covenant Violation for the Propensity-Matched Sample

The table compares changes in the interest spread for the first loan taken after covenant violation. $\Delta S p r e a d$ is defined as the interest rate of the first loan taken after a covenant violation minus the interest rate of the loan in violation. Switch lender is a dummy that equals 1 if the borrower switches to a different lead lender for the first loan taken after covenant violation. Trend Dummy equals 1 if the loan package includes one or more covenants with dynamic thresholds, and 0 otherwise. Distance to Default is estimated using the KMV Merton model (Bharath and Shumway, 2008). Capex is capital expenditures scaled by the book value of assets. Tobin's $Q$ is the market value of assets scaled by the replacement value of firm assets. Book Assets is the book value of total assets in millions of USD. ROA is income before extraordinary items, divided by the total assets. Leverage is the total amount of debt, divided by the total assets. Loan/PP\&E is the total amount of the loan granted under the package in millions scaled by net property, plant, and equipment. Financial variables are measured at the quarter of reported covenant violation. Spread is the interest spread on the package in basis points. Maturity is the maximum number of months before loan maturity granted under the package. Total Covenants is the total number of covenants. Secured equals 1 if the loan is collateralized, and 0 otherwise. Amend equals 1 if the package is an amended loan. The robust standard errors clustered by firms are reported in parentheses. $* * * p<0.01, * * p<0.05, * p<0.1$.

\begin{tabular}{|c|c|c|c|}
\hline & $\begin{array}{c}(1) \\
\Delta \text { Spread }\end{array}$ & $\begin{array}{c}(2) \\
\Delta \text { Spread }\end{array}$ & $\begin{array}{c}(3) \\
\Delta \text { Spread }\end{array}$ \\
\hline Trend Dummy & $\begin{array}{c}34.611^{* *} \\
(14.110)\end{array}$ & & $\begin{array}{c}27.910^{* *} \\
(13.698)\end{array}$ \\
\hline Switch Lender & & $\begin{array}{c}65.593^{* * *} \\
(13.913)\end{array}$ & $\begin{array}{c}62.227^{* * *} \\
(13.638)\end{array}$ \\
\hline Distance to Default & $\begin{array}{c}-6.314^{* * *} \\
(2.377)\end{array}$ & $\begin{array}{c}-4.745^{* *} \\
(2.348)\end{array}$ & $\begin{array}{c}-4.658^{*} \\
(2.373)\end{array}$ \\
\hline Tobin's Q & $\begin{array}{c}-11.441 \\
(13.752)\end{array}$ & $\begin{array}{c}-13.717 \\
(13.590)\end{array}$ & $\begin{array}{c}-11.844 \\
(13.556)\end{array}$ \\
\hline Log (Assets) & $\begin{array}{c}4.163 \\
(5.352)\end{array}$ & $\begin{array}{c}5.641 \\
(5.280)\end{array}$ & $\begin{array}{c}5.589 \\
(5.315)\end{array}$ \\
\hline $\mathrm{ROA}$ & $\begin{array}{c}-572.893^{* * *} \\
(176.040)\end{array}$ & $\begin{array}{c}-548.968^{* * *} \\
(178.268)\end{array}$ & $\begin{array}{c}-561.065^{* * *} \\
(177.068)\end{array}$ \\
\hline Leverage & $\begin{array}{l}51.380^{*} \\
(31.107)\end{array}$ & $\begin{array}{c}62.859 * * \\
(31.096)\end{array}$ & $\begin{array}{l}59.390^{*} \\
(31.079)\end{array}$ \\
\hline Capex & $\begin{array}{l}959.878^{*} \\
(506.106)\end{array}$ & $\begin{array}{l}823.841^{*} \\
(490.271)\end{array}$ & $\begin{array}{l}831.376^{*} \\
(497.645)\end{array}$ \\
\hline Loan/PP\&E & $\begin{array}{l}-5.487 \\
(3.989)\end{array}$ & $\begin{array}{l}-5.218 \\
(4.008)\end{array}$ & $\begin{array}{l}-5.320 \\
(3.975)\end{array}$ \\
\hline Secured & $\begin{array}{c}-56.753^{* * *} \\
(16.758)\end{array}$ & $\begin{array}{c}-56.803^{* * *} \\
(16.630)\end{array}$ & $\begin{array}{c}-56.941^{* * *} \\
(16.710)\end{array}$ \\
\hline Log (Maturity) & $\begin{array}{c}9.867 \\
(14.502)\end{array}$ & $\begin{array}{c}2.128 \\
(14.495)\end{array}$ & $\begin{array}{c}5.018 \\
(14.675)\end{array}$ \\
\hline Log (Total Covenants) & $\begin{array}{c}-80.189 * * * \\
(19.279)\end{array}$ & $\begin{array}{c}-76.312^{* * *} \\
(18.690)\end{array}$ & $\begin{array}{c}-79.969 * * * \\
(18.932)\end{array}$ \\
\hline Amend & $\begin{array}{c}-6.321 \\
(13.932)\end{array}$ & $\begin{array}{c}-0.754 \\
(13.887)\end{array}$ & $\begin{array}{c}-1.832 \\
(13.876)\end{array}$ \\
\hline Observations & 930 & 930 & 930 \\
\hline R-squared & 0.219 & 0.233 & 0.236 \\
\hline Industry FE & Yes & Yes & Yes \\
\hline
\end{tabular}


Table 11: Changes in Investment after Loan Origination for the Propensity-Matched Sample

This table compares the change in investment after loan origination for packages with dynamic thresholds to the changes for propensity-matched packages with constant thresholds. The dependent variable is $\Delta$ Capex(0, t), which is computed as capital expenditures measured t quarters after loan origination minus capital expenditures measured at the quarter of loan origination, where capital expenditures are scaled by the book value of assets. Trend Dummy is equal to 1 if the loan package includes one or more covenants with dynamic thresholds, and 0 otherwise. Capex Covenant equals 1 if the package includes a capital expenditure covenant, and 0 otherwise. Firm characteristics are measured as of the quarter before loan origination. Distance to Default is estimated using the KMV Merton model (Bharath and Shumway, 2008). Capex is capital expenditures scaled by the book value of assets. Tobin's $Q$ is the market value of assets scaled by the replacement value of firm assets. Book Assets is the book value of total assets in millions of USD. ROA is income before extraordinary items, divided by the total assets. Leverage is the total amount of debt, divided by the total assets. Loan/PPEE is the total amount of the loan granted under the package in millions scaled by net property, plant, and equipment. Spread is the interest spread on the package in basis points. Maturity is the maximum number of months before loan maturity granted under the package. Total Covenants is the total number of covenants. Secured equals 1 if the loan is collateralized, and 0 otherwise. Amend equals 1 if the package is an amended loan. The robust standard errors clustered by firms are reported in parentheses. $* * * p<0.01, * * p<0.05, * p<0.1$.

\begin{tabular}{|c|c|c|}
\hline & $\begin{array}{c}(1) \\
\Delta \text { Capex }[0,+4]\end{array}$ & $\begin{array}{c}(2) \\
\Delta \text { Capex }[0,+8]\end{array}$ \\
\hline Trend Dummy & $\begin{array}{l}0.257^{*} \\
(0.135)\end{array}$ & $\begin{array}{c}0.428^{* * *} \\
(0.158)\end{array}$ \\
\hline Capex Covenant & $\begin{array}{c}0.077 \\
(0.102)\end{array}$ & $\begin{array}{c}0.110 \\
(0.125)\end{array}$ \\
\hline Distance to Default & $\begin{array}{l}-0.028 \\
(0.023)\end{array}$ & $\begin{array}{l}-0.045 \\
(0.028)\end{array}$ \\
\hline Tobin's Q & $\begin{array}{l}-0.058 \\
(0.087)\end{array}$ & $\begin{array}{c}-0.209^{* *} \\
(0.101)\end{array}$ \\
\hline Log(Assets) & $\begin{array}{r}0.090^{* *} \\
(0.038)\end{array}$ & $\begin{array}{c}0.157^{* * *} \\
(0.044)\end{array}$ \\
\hline $\mathrm{ROA}$ & $\begin{array}{l}-3.338 \\
(3.851)\end{array}$ & $\begin{array}{c}4.328 \\
(4.378)\end{array}$ \\
\hline Leverage & $\begin{array}{l}-0.198 \\
(0.375)\end{array}$ & $\begin{array}{l}-0.241 \\
(0.420)\end{array}$ \\
\hline Loan/PP\&E & $\begin{array}{c}0.017 \\
(0.016)\end{array}$ & $\begin{array}{l}-0.015 \\
(0.020)\end{array}$ \\
\hline Spread & $\begin{array}{l}-0.002 \\
(0.050)\end{array}$ & $\begin{array}{c}0.013 \\
(0.059)\end{array}$ \\
\hline Secured & $\begin{array}{l}-0.019 \\
(0.185)\end{array}$ & $\begin{array}{l}-0.114 \\
(0.197)\end{array}$ \\
\hline Log(Maturity) & $\begin{array}{l}-0.009 \\
(0.130)\end{array}$ & $\begin{array}{c}0.023 \\
(0.156)\end{array}$ \\
\hline Log (Total Covenants) & $\begin{array}{l}-0.034 \\
(0.137)\end{array}$ & $\begin{array}{c}0.015 \\
(0.144)\end{array}$ \\
\hline Amend & $\begin{array}{c}0.047 \\
(0.149)\end{array}$ & $\begin{array}{l}-0.037 \\
(0.168)\end{array}$ \\
\hline $\begin{array}{l}\text { Observations } \\
\text { R-squared } \\
\text { Industry FE }\end{array}$ & $\begin{array}{c}4879 \\
0.046 \\
\text { Yes }\end{array}$ & $\begin{array}{c}4426 \\
0.100 \\
\text { Yes }\end{array}$ \\
\hline
\end{tabular}


Table 12: Capex Covenant and Dynamic Thresholds in Financial Covenants for the Propensity-Matched Sample

This table reports determinants of Capex covenants in a loan package using the FRM model with a logit link function for the propensity-matched sample. The dependent variable in Column (1) is a dummy variable that indicates whether a loan package includes a Capex covenant. The dependent variable in Columns (2) and (3) is equal to 1 if a loan package includes a Capex covenant that allows firms to increase capital expenditures over time, and 0 otherwise. The sample used in Column (3) is restricted to those loan packages that include Capex covenants. Trend Dummy is equal to 1 if the loan package includes at least one covenant with dynamic thresholds, and 0 otherwise. Distance to Default is estimated using the KMV Merton model (Bharath and Shumway, 2008). Capex is capital expenditures scaled by the book value of assets. Tobin's $Q$ is the market value of assets scaled by the replacement value of firm assets. Book Assets is the book value of total assets in millions of USD. ROA is income before extraordinary items, divided by the total assets. Leverage is the total amount of debt, divided by the total assets. Loan/PPEE is the total amount of the loan granted under the package in millions scaled by net property, plant, and equipment. Financial variables are measured as of the quarter before loan origination. Spread is the interest spread on the package in basis points. Maturity is the maximum number of months before loan maturity granted under the package. Total Covenants is the total number of covenants. Secured equals 1 if the loan is collateralized, and 0 otherwise. Amend equals 1 if the package is an amended loan. The robust standard errors clustered by firms are reported in parentheses. $* * * p<0.01, * * p<0.05, * p<0.1$.

\begin{tabular}{|c|c|c|c|}
\hline & $\begin{array}{c}(1) \\
\text { Capex Covenant }\end{array}$ & $\begin{array}{c}(2) \\
\text { Allowing Increasing } \\
\text { Capex }\end{array}$ & $\begin{array}{c}(3) \\
\text { Allowing Increasing } \\
\text { Capex }\end{array}$ \\
\hline Trend Dummy & $\begin{array}{c}0.336^{* * *} \\
(0.077)\end{array}$ & $\begin{array}{c}0.453^{* * *} \\
(0.110)\end{array}$ & $\begin{array}{c}0.339^{* * *} \\
(0.131)\end{array}$ \\
\hline Distance to Default & $\begin{array}{c}-0.078^{* * *} \\
(0.013)\end{array}$ & $\begin{array}{c}-0.049^{* *} \\
(0.020)\end{array}$ & $\begin{array}{c}0.005 \\
(0.021)\end{array}$ \\
\hline Capex & $\begin{array}{c}-6.372^{* * *} \\
(2.268)\end{array}$ & $\begin{array}{l}-0.099 \\
(3.057)\end{array}$ & $\begin{array}{c}3.880 \\
(3.625)\end{array}$ \\
\hline Tobin's Q & $\begin{array}{l}-0.020 \\
(0.057)\end{array}$ & $\begin{array}{c}0.076 \\
(0.074)\end{array}$ & $\begin{array}{c}0.078 \\
(0.081)\end{array}$ \\
\hline Log (Assets) & $\begin{array}{c}-0.176^{* * *} \\
(0.031)\end{array}$ & $\begin{array}{c}-0.134^{* * *} \\
(0.043)\end{array}$ & $\begin{array}{l}-0.038 \\
(0.051)\end{array}$ \\
\hline $\mathrm{ROA}$ & $\begin{array}{l}-1.013 \\
(1.222)\end{array}$ & $\begin{array}{c}1.095 \\
(1.912)\end{array}$ & $\begin{array}{c}0.990 \\
(2.298)\end{array}$ \\
\hline Leverage & $\begin{array}{c}-0.459^{* *} \\
(0.225)\end{array}$ & $\begin{array}{c}0.330 \\
(0.285)\end{array}$ & $\begin{array}{l}0.627^{*} \\
(0.332)\end{array}$ \\
\hline Loan/PP\&E & $\begin{array}{c}-0.035^{* * *} \\
(0.007)\end{array}$ & $\begin{array}{l}-0.017^{*} \\
(0.010)\end{array}$ & $\begin{array}{c}0.000 \\
(0.012)\end{array}$ \\
\hline Spread & $\begin{array}{c}0.176^{* * *} \\
(0.034)\end{array}$ & $\begin{array}{c}0.222^{* * *} \\
(0.040)\end{array}$ & $\begin{array}{c}0.199 * * * \\
(0.051)\end{array}$ \\
\hline Log (Maturity) & $\begin{array}{c}0.038 \\
(0.081)\end{array}$ & $\begin{array}{l}0.190^{*} \\
(0.108)\end{array}$ & $\begin{array}{c}0.296^{* *} \\
(0.140)\end{array}$ \\
\hline Secured & $\begin{array}{c}0.578^{* * *} \\
(0.126)\end{array}$ & $\begin{array}{c}0.814^{* * *} \\
(0.239)\end{array}$ & $\begin{array}{l}0.461^{*} \\
(0.263)\end{array}$ \\
\hline Log (Total Covenants) & $\begin{array}{c}2.486^{* * *} \\
(0.115)\end{array}$ & $\begin{array}{c}1.482^{* * *} \\
(0.177)\end{array}$ & $\begin{array}{l}-0.027 \\
(0.215)\end{array}$ \\
\hline Amend & $\begin{array}{c}0.133 \\
(0.091)\end{array}$ & $\begin{array}{c}0.175 \\
(0.134)\end{array}$ & $\begin{array}{c}0.155 \\
(0.159)\end{array}$ \\
\hline Observations & 5,446 & 5,446 & 1,840 \\
\hline Pseudo R-squared & 0.346 & 0.250 & 0.162 \\
\hline Industry \& Year-Qtr FE & Yes & Yes & Yes \\
\hline
\end{tabular}




\section{Table 13: Covenant Restrictiveness at Loan Package Level for the Propensity-Matched Sample}

This table shows the results of the association between the presence of dynamic covenant thresholds and covenant restrictiveness for the propensity-matched sample. Strictness is overall covenant restrictiveness, estimated at the loan package level using the model from Murfin (2012). $\Delta$ Strictness is the maximum of the final strictness minus the initial strictness scaled by loan maturity. Avg. Strictness is the average of the final strictness and the initial strictness. Trend Dummy equals 1 if the loan package includes one or more covenants with dynamic thresholds, and 0 otherwise. Distance to Default is estimated using the KMV Merton model (Bharath and Shumway, 2008). Capex is capital expenditures scaled by the book value of assets. Tobin's $Q$ is the market value of assets scaled by the replacement value of firm assets. Book Assets is the book value of total assets in millions of USD. ROA is income before extraordinary items, divided by the total assets. Leverage is the total amount of debt, divided by the total assets. Loan/PPEE is the total amount of the loan granted under the package in millions scaled by net property, plant, and equipment. Financial variables are measured as of the quarter before loan origination. Spread is the interest spread on the package in basis points. Maturity is the maximum number of months before loan maturity granted under the package. Total Covenants is the total number of covenants. Secured equals 1 if the loan is collateralized, and 0 otherwise. Amend equals 1 if the package is an amended loan. The robust standard errors clustered by firms are reported in parentheses. $* * * p<0.01, * * p<0.05, p<0.1$.

\begin{tabular}{|c|c|c|c|}
\hline & $\begin{array}{c}(1) \\
\text { Strictness }\end{array}$ & $\begin{array}{c}(2) \\
\Delta \text { Strictness }\end{array}$ & $\begin{array}{c}(3) \\
\text { Avg. Strictness }\end{array}$ \\
\hline Trend Dummy & $\begin{array}{c}8.205^{* * *} \\
(0.963)\end{array}$ & $\begin{array}{c}0.678^{* * *} \\
(0.129)\end{array}$ & $\begin{array}{c}10.407^{* *} \\
(1.479)\end{array}$ \\
\hline Distance to Default & $\begin{array}{c}-0.774^{* * * *} \\
(0.163)\end{array}$ & $\begin{array}{c}-0.080^{* * * *} \\
(0.021)\end{array}$ & $\begin{array}{c}-2.174^{* * *} \\
(0.248)\end{array}$ \\
\hline Capex & $\begin{array}{l}-52.199 \\
(33.202)\end{array}$ & $\begin{array}{l}6.469^{*} \\
(3.548)\end{array}$ & $\begin{array}{l}65.303^{*} \\
(37.879)\end{array}$ \\
\hline Tobin's Q & $\begin{array}{l}-0.657 \\
(0.612)\end{array}$ & $\begin{array}{c}0.083 \\
(0.148)\end{array}$ & $\begin{array}{c}-2.977^{* * *} \\
(0.945)\end{array}$ \\
\hline Log (Assets) & $\begin{array}{c}-0.979 * * \\
(0.445)\end{array}$ & $\begin{array}{l}0.125^{*} \\
(0.068)\end{array}$ & $\begin{array}{l}-0.328 \\
(0.555)\end{array}$ \\
\hline $\mathrm{ROA}$ & $\begin{array}{l}-44.290^{*} \\
(25.766)\end{array}$ & $\begin{array}{c}-11.088^{* *} \\
(4.509)\end{array}$ & $\begin{array}{c}-113.960^{* * *} \\
(23.552)\end{array}$ \\
\hline Leverage & $\begin{array}{c}34.381 * * * \\
(3.595)\end{array}$ & $\begin{array}{c}0.334 \\
(0.501)\end{array}$ & $\begin{array}{c}17.610^{* * *} \\
(6.239)\end{array}$ \\
\hline Loan/PP\&E & $\begin{array}{l}-0.159 \\
(0.121)\end{array}$ & $\begin{array}{c}0.015 \\
(0.013)\end{array}$ & $\begin{array}{l}-0.021 \\
(0.143)\end{array}$ \\
\hline Spread & $\begin{array}{c}-1.304^{*} \\
(0.697)\end{array}$ & $\begin{array}{c}0.310^{* * *} \\
(0.110)\end{array}$ & $\begin{array}{c}3.098^{* * *} \\
(0.745)\end{array}$ \\
\hline Log (Maturity) & $\begin{array}{l}1.766^{*} \\
(1.024)\end{array}$ & $\begin{array}{c}0.500^{* *} \\
(0.227)\end{array}$ & $\begin{array}{l}-2.113 \\
(1.785)\end{array}$ \\
\hline Secured & $\begin{array}{l}-1.299 \\
(1.279)\end{array}$ & $\begin{array}{c}-2.187^{* * *} \\
(0.318)\end{array}$ & $\begin{array}{l}-1.855 \\
(1.541)\end{array}$ \\
\hline Log (Total Covenants) & $\begin{array}{c}2.601^{* *} \\
(1.163)\end{array}$ & $\begin{array}{c}-0.337^{* *} \\
(0.149)\end{array}$ & $\begin{array}{c}0.055 \\
(1.672)\end{array}$ \\
\hline Amend & $\begin{array}{c}0.759 \\
(1.048)\end{array}$ & $\begin{array}{c}-0.322^{*} \\
(0.196)\end{array}$ & $\begin{array}{c}10.335^{* * *} \\
(1.641)\end{array}$ \\
\hline Observations & 1,804 & 1,804 & 1,804 \\
\hline R-squared & 0.331 & 0.334 & 0.360 \\
\hline Industry \& Year-Qtr FE & Yes & Yes & Yes \\
\hline
\end{tabular}

